\title{
Martwe drzewa w łęu jesionowo-olszowym Fraxino-Alnetum w rezerwacie przyrody „Ochojec” w Katowicach
}

\author{
JERZY B. PARUSEL
}

\begin{abstract}
Parusel, J. B. 2020. Dead trees in Fraxino-Alnetum ash-alder forest in the Ochojec Nature Reserve (Katowice, Poland). Fragmenta Floristica et Geobotanica Polonica 27(1): 169-189. Kraków. e-ISSN 2449-8890, ISSN 1640-629X.

ABSTRACT: The paper presents changes in the structure of a Fraxino-Alnetum stand in a permanent study plot established in 1979 in the Ochojec Nature Reserve in Katowice. During the research period (1979-2019), 17 tree and shrub species were found on the plot. The dominant species of the stand is black alder. Pedunculate oak and rowan dominated among saplings. The volume of timber increased from 247.99 to $527.36 \mathrm{~m}^{3} /$ ha during the study period. The share of standing dead trees in the stand was small: 5 trees in $1987(0.90 \% \mathrm{~N} / \mathrm{ha}$ and $0.02 \% \mathrm{~V} / \mathrm{ha}$ of living trees) and 51 trees in $2019(11.80 \%, 0.84 \%)$. Oak and rowan dominated in quantity, and black alder in volume. Lying dead trees form the coarse woody debris. In 2004, 147 trees (which were measured as standing in 1987) with a total volume of $15.86 \mathrm{~m}^{3} /$ ha were lying on the forest floor. In 2019 , another 174 trees (measured as standing in 2004) with a total volume of $24.82 \mathrm{~m}^{3} /$ ha were on the forest floor. In this category as well, oak and rowan dominated in quantity, and black alder in volume.
\end{abstract}

KEY WORDS: dead trees, forest stand dynamics, forest stand structure, Fraxino-Alnetum, Ochojec Nature Reserve

J. B. Parusel, Centrum Dziedzictwa Przyrody Górnego Ślqska, ul. Graniczna 29, 40-017 Katowice, Polska; e-mail: j.parusel@cdpgs.katowice.pl

\section{WSTĘP}

Martwe drzewa są integralnym i ważnym elementem struktury drzewostanów i funkcjonowania ekosystemu leśnego. Wraz z zasiedlającymi je wyspecjalizowanymi organizmami żywymi stanowią one o różnorodności biologicznej i produktywności ekosystemów leśnych oraz retencji węgla (MASER \& TRAPPE 1984; HARMON i in. 1986; SOlON 2002; GuTOwSKI i in. 2004; Merganičová i in. 2012; Stokland i in. 2012; Kraus \& Krumm 2013; DitTRICH i in. 2014; TABOR 2014; PAWLACZYK 2016; BEHNKE-BOROWCZYK i in. 2018). Biomasa martwych drzew jest ważnym wskaźnikiem oceny stanu lasu (SCHUCK i in. 2004; EUROPEAN EnVironmental AgEncy 2015; Gao i in. 2015), jego naturalności (KuntTu i in. 2015) oraz oceny prowadzenia zrównoważonej gospodarki leśnej (MÜLLER \& BÜTLER 2010; CZEREPKO $i$ in. 2014; Holeksa i in. 2014; ReFerowska-ChodaK 2014; SEIDling i in. 2014; Forest SteWARDShIP COUNCIL 2015; VÍTKOVÁ i in. 2018; ZIELONKA i in. 2018). 
Obszary chronione, w tym parki narodowe i rezerwaty przyrody, pełnią ważną rolę w retencji martwych drzew w ekosystemach leśnych, zwłaszcza drzew wielkowymiarowych. Wskazują na to wyniki badań LINDERA i in. (1997), HAHN i CHRISTENSENA (2004), CHRISTENSENA $\mathrm{i}$ in. (2005), a także wyniki wielkoobszarowej inwentaryzacji stanu lasu w Polsce (Wielkoobszarowa inwentaryzacja 2019).

W województwie śląskim badania dotyczące martwych drzew w rezerwatach przyrody są nieliczne - były one przeprowadzone w 17 spośród 65 dotychczas utworzonych ${ }^{1}$. Do tej pory opublikowano wyniki badań dla następujących rezerwatów: „Kopce” (PASIERBEK i in. 2007), „Las Murckowski” (MAŚLAK \& ORCZEWSKA 2010), „Madohora” (KARCZMARSKI \& BĄK 2010; PASIERBEK i in. 2007), „Ochojec” (PARUSEl 2009b), „Oszast” (JAwOrSKi i in. 2001b; Jaworski \& PACh 2014; PASIERbeK i in. 2007), „Pod Rysianką” (PASIERbeK i in. 2007), „Romanka” (KarcZMARski \& KowalcZuK 2007), „Segiet” (MAŚLAK \& OrCZEWsKA 2010; PASIERBEK i in. 2007), „Skarpa Wiślicka” (ChMURA i in. 2017), „Stok Szyndzielni” (PASIERbeK i in. 2007), „Szeroka” (PASIERBEK i in. 2007) oraz „Śrubita” (JAWORSKi i in. 2001a). Ostatnio, w trakcie badań koleopterologicznych, były także inwentaryzowane martwe drzewa w rezerwatach: „Babczyna Dolina”, „Dębowa Góra”, „Hubert”, „Las Murckowski”, „Łężczok”, „Modrzewiowa Góra” i „Segiet” (KARPIŃsKi 2017).

Rezerwat przyrody „Ochojec” jest częściowym rezerwatem florystycznym, utworzonym Zarządzeniem Ministra Leśnictwa i Przemysłu Drzewnego z dnia 26 marca 1982 r. w sprawie uznania za rezerwaty przyrody (MP nr $10 \mathrm{z}$ dnia 6.04.1982 r., poz. 74) w celu ochrony stanowiska liczydła górskiego. Położony jest w mieście Katowice, Nadleśnictwie Katowice i zajmuje obecnie powierzchnię 25,79 ha (Zarządzenie Regionalnego Dyrektora Ochrony Środowiska w Katowicach z dnia 21 czerwca 2019 r. w sprawie rezerwatu przyrody „Ochojec”; Dz. Urz. Woj. Śl. z dnia 25 czerwca 2019 r., poz. 4598). Roślinność rezerwatu reprezentowana jest przez 50 syntaksonów, w tym przez 9 leśnych. Zespoły leśne dominują pod względem liczby płatów (ponad 63\% liczby wszystkich skartowanych płatów) i zajmowanej powierzchni (ponad 90\% powierzchni rezerwatu). Największą powierzchnię spośród nich zajmują: Querco roboris-Pinetum - 12,11 ha, Luzulo pilosae-Fagetum - 4,22 ha, Calamagrostio villosae-Pinetum - 3,35 ha i Fraxino-Alnetum - 2,32 ha (PARUSEL 2009a; PARUSEL \& BULA 2009).

W rezerwacie przyrody „Ochojec” martwe drzewa stały się obiektem badań od 1987 r., w którym przystąpiono do pomiarów drzew martwych, stojących na stałej powierzchni badawczej założonej w 1979 r., w drzewostanie reprezentującym zespół Fraxino-Alnetum (PARUSEL 2009b). Powierzchnia ta została założona w celu monitorowania zmian struktury lasu olszowego, w którym występuje populacja liczydła górskiego (Streptopus amplexifolius) - przedmiot ochrony w rezerwacie i badań na dwóch stałych powierzchniach od 1982 r. (PARUSEL 2003). Należy podkreślić, że założona powierzchnia badawcza była swoistą formą ochrony populacji liczydła górskiego, zanim powstał rezerwat przyrody.

W latach 2007-2010 zostały w rezerwacie wykonane przez studentów Uniwersytetu Śląskiego w Katowicach dwie prace magisterskie, których tematem były martwe drzewa (COFAŁA 2009; GóraK 2010).

\footnotetext{
1 Zbiorowiska leśne są przedmiotem ochrony lub dominującym elementem przyrody w większości z nich.
} 
Celem niniejszej pracy jest przedstawienie wyników długoterminowych badań własnych nad strukturą i dynamiką martwych drzew w łęgu jesionowo-olszowym w warunkach częściowej ochrony rezerwatowej. Wyniki tych badań odniesiono do danych zebranych dla drzew żywych, które będą przedmiotem odrębnej publikacji.

\section{MATERIAŁY I METODY}

\section{Powierzchnia badawcza}

Powierzchnię badawczą założono wiosną 1979 r. w ówczesnym wydzieleniu 41f (obecnie 41h) (Ryc. 1). Powierzchnia o wielkości 0,57 ha ma kształt nieregularny, a swoimi granicami obejmuje płat łęgu jesionowo-olszowego Fraxino-Alnetum, usytuowany w bocznej dolince erozyjnej (denudacyjnej) na prawym zboczu doliny Ślepiotki (PARUSEL \& BULA 2009). Wszystkie załamania granicy zostały trwale oznakowane rurkami PCV, a drzewa na granicy powierzchni zostały oznakowane białą farbą olejną. W $1987 \mathrm{r}$. ponumerowano i oznakowano trwale białą farbą olejną wszystkie drzewa i krzewy o pierśnicy od $5 \mathrm{~cm}$, co umożliwia śledzenie losu każdego osobnika, natomiast w 2012 r. została sporządzona mapa rozmieszczenia wszystkich pomierzonych drzew stojących. W 2019 r. odnowiono oznakowanie drzew i powierzchni.

Opis taksacyjny drzewostanu w 1976 r. w wydzieleniu 41f (1,02 ha) był następujący: 9 Olcha, 1 Sosna, sporadycznie dąb, wiąz, brzoza, buk, świerk (81-90) 85 lat; zwarcie umiarkowane; podszyt $50 \%$ - bez, kruszyna, dąb, jarzębina; zadrzewienie 0,8 ; przeciętna średnica olchy $-35 \mathrm{~cm}$, sosny $-28 \mathrm{~cm}$, średnia wysokość olchy - $22 \mathrm{~m}$, sosny - $17 \mathrm{~m}$; bonitacja III/IV; zapas: olcha $-230 \mathrm{~m}^{3}$, sosna - $30 \mathrm{~m}^{3}$; siedlisko: Ols jesionowy, gleba: bagienna, murszowo-torfowa (PLAN URZĄDZENIA 1976). Opis taksacyjny drzewostanu w $2010 \mathrm{r}$. (wydzielenie 41h, pow. 0,57 ha) był następujący: 9 Olcha, 1 Dąb 115 lat, miejscami brzoza, buk, sosna 115 lat, zwarcie umiarkowane, zadrzewienie 0,9; podrost II 4 Olcha, 3 Dąb, 3 Jesion 30 lat, zadrzewienie 0,2; podszyt: czeremcha, bez czarny, kruszyna, jarzębina 50\%; przeciętna pierśnica olchy $-40 \mathrm{~cm}$, dębu $-44 \mathrm{~cm}$, wysokość - $26 \mathrm{~m}$; bonitacja II/III; zapas: olcha $-230 \mathrm{~m}^{3}$, dąb $-25 \mathrm{~m}^{3}$; siedlisko: Ols, gleba: murszasta na piasku gliniastym zalegającym na piasku zwykłym (Plan URZĄDZENIA 2010).

Drzewostan na powierzchni próbnej podlegał czynnościom gospodarczo-leśnym, zarówno przed jak i po utworzeniu rezerwatu przyrody. Prowadzenie cięć sanitarnych obserwowano w latach 1983, 1987 (PARusel 1989), 1990 i 1993 (wycięto wówczas ponad 100 drzew, głównie dębów, brzóz i jarzębin, co uwidaczniają wyniki pomiarów własnych z 2004 r.). Przed 2019 r. zostały wycięte dwa martwe drzewa, które zagrażały ogrodzeniu stanowiska liczydła górskiego. Wszystkie wycięte drzewa nie były usuwane z powierzchni próbnej.

W lipcu 2001 r. lasy murckowskie nawiedził huraganowy wiatr, który powalił i połamał drzewa na znacznym obszarze. Na powierzchni próbnej zostały uszkodzone pnie 12 żywych i jednej martwej olszy czarnej, a jedna została złamana w nasadzie pnia i nie została objęta pomiarami w $2004 \mathrm{r}$.

W 2006 r. powierzchnia próbna znalazła się wewnątrz wysokiego ogrodzenia z siatki leśnej, które zabezpiecza populację liczydła górskiego przed buchtowaniem dzików. Ogrodzenie nie jest jednak szczelne i okresowo dochodzi do penetracji powierzchni przez kopytnych roślinożerców, wykorzystujących uszkodzenia spowodowane przez człowieka (przecinanie siatki) lub czynniki losowe (wywroty i złomy drzew).

\section{Metoda pomiarów i obliczeń}

Pierwszego pomiaru drzewostanu dokonano w 1979 r., przyjmując próg pomiaru pierśnicy $7 \mathrm{~cm}$. Pomierzono pierśnice wszystkich żywych drzew i krzewów, których środki pni położone były w granicach powierzchni próbnej, oraz wysokości 19 olch czarnych, dwóch wiązów górskich i 11 dębów szypułkowych w celu wykreślenia krzywej wysokości. W 1987 r., w granicach powierzchni próbnej dokonano pomiaru 


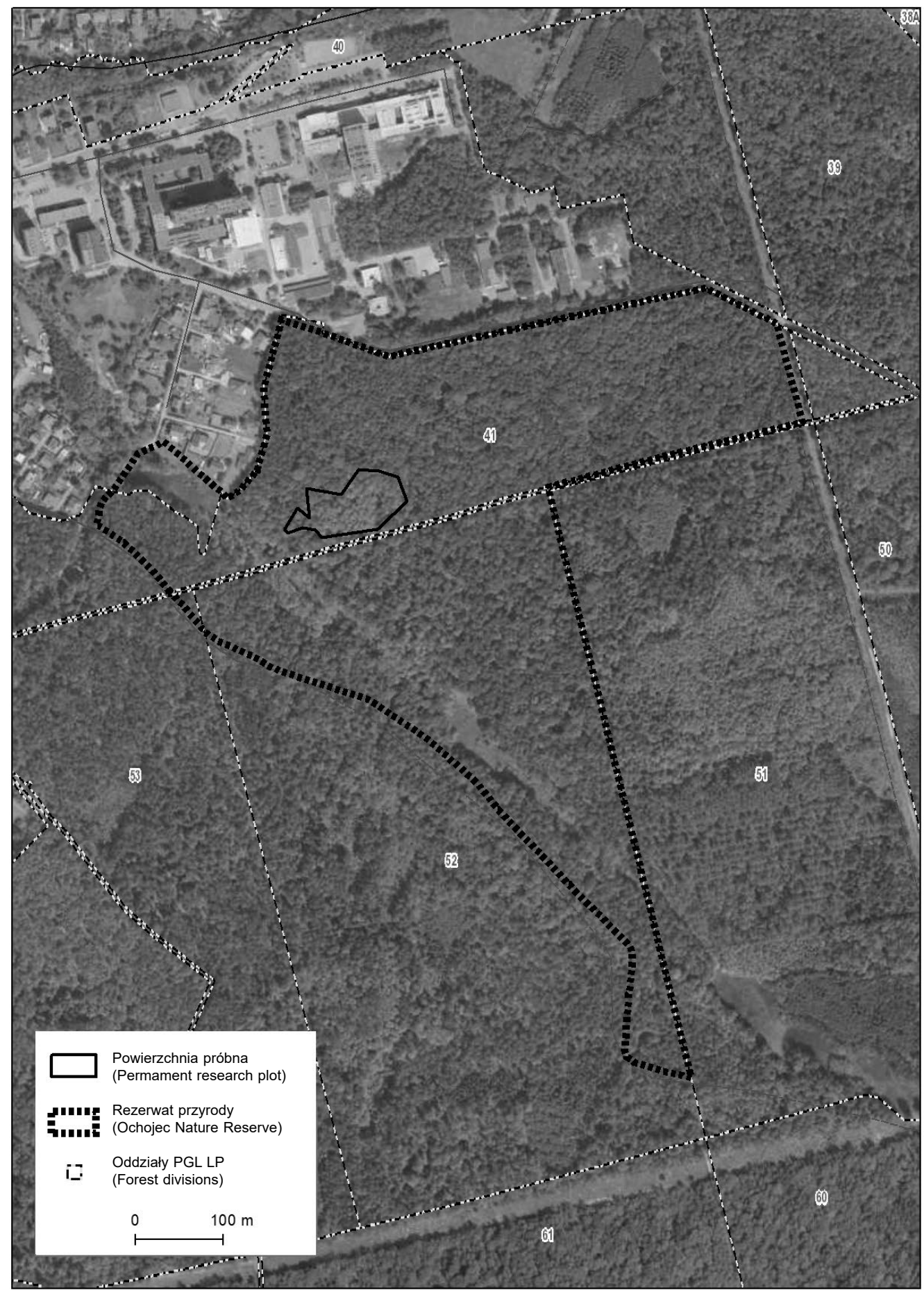

Ryc. 1. Położenie stałej powierzchni badawczej w rezerwacie przyrody „Ochojec” w Katowicach

Fig. 1. Location of the permanent research plot in the Ochojec Nature Reserve in Katowice 
wszystkich drzew i krzewów (żywych i martwych) o pierśnicy od $5 \mathrm{~cm}$ oraz nasady ich koron. Następne pomiary, wykonane w ten sam sposób, przeprowadzono w latach 2004 i 2019.

Pomiary drzew i krzewów martwych dotyczyły wyłącznie osobników stojących i położonych w granicach powierzchni próbnej, które na wysokości $1,30 \mathrm{~m}$ osiągnęły pierśnicę $5 \mathrm{~cm}$. Wśród nich wyróżniano drzewa i krzewy martwe stojące, do których zaliczano całe lub nieznacznie uszkodzone drzewa i krzewy martwe, oraz złomy - czyli fragmenty drzew i krzewów martwych o wysokości powyżej 1,30 m. Nie badano martwych drzew i krzewów leżących (zarówno całych, jak i fragmentów czy wykrotów) oraz innych rodzajów drzew i krzewów martwych (pniaki, posusz wiszący) i stopnia ich rozkładu.

W celu oszacowania objętości martwych drzew i krzewów leżących uznano, że są to te drzewa i krzewy, które zostały zainwentaryzowane jako stojące w poprzednim okresie pomiarowym, a stwierdzono ich brak w bieżącym okresie pomiarowym. Za ich objętość przyjęto miąższość, gdy były jeszcze składnikiem drzewostanu w poprzednim okresie pomiarowym. Szacunek ten może być obarczony błędem, gdyż nie uwzględnia on drzew leżących na powierzchni już w pierwszym terminie pomiarowym (1979 r.), a także z uwagi na zmianę wymiarów tych drzew i krzewów pomiędzy okresem pomiarowym, a czasem ich faktycznego wypadnięcia z drzewostanu, jak również wskutek procesu dekompozycji oraz sposobu depozycji drzew i krzewów na powierzchni (fragmenty pni i kłód położone poza powierzchnią). Należy przypuszczać, że uzyskane w ten sposób wyniki mogą być zaniżone.

Obliczenia miąższości grubizny drzewostanu w 1979 r. wykonano metodą krzywych wysokości, a w pozostałych terminach metodą stopni grubości. Korzystano w tym celu z tablic miąższości drzew stojących CzURAJA i in. (1966). Do obliczenia miąższości grubizny drzew i krzewów gatunków innych niż olsza i dąb, wykorzystano tabelę dla dębu CzuraJA i in. (1966). Obliczeń dokonano odrębnie dla drzew żywych i martwych stojących. Wyniki obliczeń miąższości dla olszy czarnej i wiązu górskiego oraz dla dębów szypułkowego i bezszypułkowego zsumowano dla obu tych grup gatunków razem. W przypadku złomów do obliczenia ich miąższości zastosowano wzór środkowego przekroju Hubera (BRUCHWALD 1986). Średnicę środkową pnia mierzono bezpośrednio lub szacowano na podstawie jego zbieżystości poprzez pomocniczy pomiar średnicy na wysokości 2,0 i 2,5 m od nasady pnia. Z tablic CzURAJA i in. (1966) odczytano także powierzchnię przekroju poprzecznego drzew.

Bonitację drzewostanu odczytano z tablic CzURAJA (1990) dla wysokości drzewostanu obliczonej wzorem Loreya (BRUCHWALD 1986), która dla poszczególnych terminów pomiarów wynosiła: 19,9, 23,0, 24,2 i $26,7 \mathrm{~m}$.

W obliczeniach dendrometrycznych zrezygnowano z wzorów i tablic opracowanych dla olszy czarnej przez DudZiŃSKą i BRUCHWALDA (2003), z których korzystano poprzednio (PARUSEL 2009b), a w niniejszej pracy zamieszczono poprawione i zweryfikowane dane dendrometryczne za cały okres pomiarowy 1979-2019, obliczone zgodnie z przedstawioną metodyką. Wszystkie wyniki pomiarów przeliczono na 1 ha.

\section{WYNIKI}

\section{Drzewostan (drzewa żywe)}

W badanym drzewostanie w latach 1979-2019 stwierdzono w sumie 17 gatunków drzew i krzewów, lecz tylko 6 z nich (Alnus glutinosa, Betula pendula, Fagus sylvatica, Quercus robur, Sorbus aucuparia, Ulmus glabra) było obecnych przez cały okres badań. W 1987 r. przybyło 5 gatunków (Betula pubescens, B. pendula subsp. obscura, Frangula alnus, Quercus petraea, Sambucus nigra), w 2004 r. przybyły dwa gatunki (Malus sylvestris, Padus serotina), a w czasie ostatniego pomiaru w 2019 r. zanotowano Tilia cordata. Z drzewostanu ubyły: B. pendula subsp. obscura, F. alnus, Picea abies, Populus tremula, Salix caprea, Sambucus racemosa.

Najliczniejszym gatunkiem w drzewostanie była Alnus glutinosa, której liczebność wynosiła od 260 do 311 sztuk, a udział procentowy od 49 do ponad 60\%. Sporadycznie 

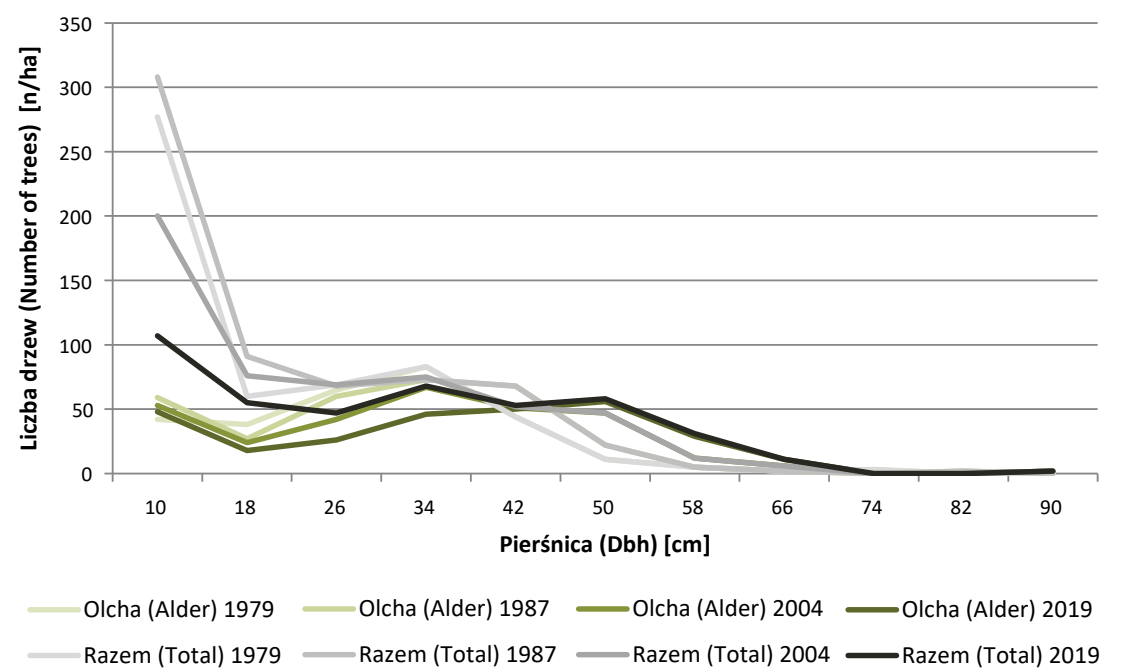

Ryc. 2. Rozkład pierśnic drzew żywych w badanym drzewostanie jesionowo-olszowym w rezerwacie przyrody „Ochojec” w latach 1979-2019

Fig. 2. Diameter at breast height (Dbh) distribution of living trees in the studied ash-alder forest stand in the Ochojec Nature Reserve in 1979-2019

w warstwie drzew występowały: Betula pendula, Fagus sylvatica, Quercus robur i Ulmus glabra $^{2}$. W dolnym piętrze notowano głównie $Q$. robur i B. pendula. Zwraca uwagę zarejestrowanie w 1987 r. podrostów U. glabra, F. sylvatica i B. pubescens. W podszycie dominowała Sorbus aucuparia. W 2004 r. próg pomiaru przekroczyły Malus sylvestris i obca Padus serotina, a w 2019 r. - Tilia cordata. Liczebność drzew w badanym okresie uległa zmniejszeniu: olszy czarnej i wiązu górskiego o 7 drzew (2,4\%), dębów - o 95 drzew (57,6\%), a całego drzewostanu - o 122 drzewa (22,0\%) (Tab. 1).

Rozkład grubości drzew całego drzewostanu był lewoskośny (Ryc. 2), z największą liczbą drzew w najniższych stopniach grubości. Taka krzywa jest efektem nałożenia się rozkładów podrostów i podszytów, o największej frekwencji w niższych stopniach grubości, oraz rozkładu olszy czarnej i wiązu górskiego z większą frekwencją w wyższych stopniach grubości. Powierzchnia przekroju pierśnicowego drzew zwiększyła się: u olszy czarnej i wiązu górskiego o 12,99 $\mathrm{m}^{2} /$ ha $(52,4 \%)$, dębów - o 2,79 $\mathrm{m}^{2} /$ ha (aż o 296,3\%), a dla całego drzewostanu - o $16,45 \mathrm{~m}^{2} /$ ha $(60,8 \%)$ (Tab. 1). Średnia pierśnica olszy czarnej i wiązu górskiego wzrosła o 6,9 cm (22,7\%), natomiast dębów - aż o 15,2 cm (253,3\%). Dla drzew całego drzewostanu średnica ta wzrosła o $10,5 \mathrm{~cm}(50,4 \%)$ (Tab. 1). Średnia powierzchnia przekroju pierśnicowego pni olszy czarnej i wiązu górskiego wzrosła o $0,05 \mathrm{~m}^{2} / \mathrm{ha}(54,1 \%)$, a dębów o $0,05 \mathrm{~m}^{2} /$ ha (aż o $725 \%$ ). Dla wszystkich drzew w drzewostanie wzrost ten wynosił $0,05 \mathrm{~m}^{2} /$ ha $(204,1 \%)$.

\footnotetext{
2 Najstarszy i najgrubszy wiąz w 1979 r. miał $75 \mathrm{~cm}$ pierśnicy i 27 m wysokości. Podrosty wiązu pochodzą z tego właśnie drzewa, które nie dotrwało do pomiaru w $1987 \mathrm{r}$.
} 
Tabela 1. Zmiany struktury drzew żywych w badanym drzewostanie jesionowo-olszowym w rezerwacie przyrody „Ochojec" w latach 1979-2019

Table 1. Structural changes of living trees in the studied ash-alder forest stand in the Ochojec Nature Reserve in 1979-2019

\begin{tabular}{|c|c|c|c|c|c|}
\hline \multirow{2}{*}{$\begin{array}{l}\text { Cecha } \\
\text { (Characteristic) }\end{array}$} & \multirow{2}{*}{$\begin{array}{l}\text { Rok } \\
\text { (Year) }\end{array}$} & \multicolumn{3}{|c|}{ Gatunek (Species) } & \multirow{2}{*}{$\begin{array}{l}\text { Razem } \\
\text { (Total) }\end{array}$} \\
\hline & & $\begin{array}{l}\text { Olcha }^{1} \\
\text { (Alder) }\end{array}$ & $\begin{array}{l}\mathrm{Dacb}^{2} \\
(\mathrm{Oak})\end{array}$ & $\begin{array}{l}\text { Inne } \\
\text { (Other) }\end{array}$ & \\
\hline \multicolumn{6}{|c|}{ Cechy struktury drzewostanu (Structural characters of forest stand) } \\
\hline \multirow{4}{*}{$\begin{array}{l}\mathrm{N} \\
{[\mathrm{n} / \mathrm{ha}]}\end{array}$} & 1979 & 293 & 165 & 96 & 554 \\
\hline & 1987 & $314 / 4$ & 211 & 110 & $635 / 4$ \\
\hline & 2004 & $281 / 23$ & $126 / 2$ & 107 & $514 / 25$ \\
\hline & 2019 & 286 & 70 & 76 & 432 \\
\hline \multirow{4}{*}{$\begin{array}{l}\mathrm{G} \\
{\left[\mathrm{m}^{2} / \mathrm{ha}\right]}\end{array}$} & 1979 & 24,759 & 1,421 & 0,874 & 27,054 \\
\hline & 1987 & $27,040 / 0,375$ & 2,654 & 1,144 & $30,838 / 0,375$ \\
\hline & 2004 & $30,576 / 2,117$ & $3,415 / 0,125$ & 1,230 & $35,221 / 2,242$ \\
\hline & 2019 & 37,747 & 4,210 & 1,548 & 43,505 \\
\hline \multirow{4}{*}{$\begin{array}{l}\mathrm{V} \\
{\left[\mathrm{m}^{3} / \mathrm{ha}\right]}\end{array}$} & 1979 & 240,07 & 4,73 & 3,19 & 247,99 \\
\hline & 1987 & $294,54 / 2,84$ & 14,76 & 6,76 & $316,05 / 2,84$ \\
\hline & 2004 & $353,18 / 16,86$ & $28,65 / 0,72$ & 10,46 & $392,29 / 17,58$ \\
\hline & 2019 & 465,12 & 47,17 & 15,07 & 527,36 \\
\hline
\end{tabular}

Średnie cechy biometryczne drzew żywych (Average biometric characters of living trees)

\begin{tabular}{|c|c|c|c|c|c|}
\hline \multirow{4}{*}{$\begin{array}{l}\overline{\mathrm{D}} \\
{[\mathrm{cm}]}\end{array}$} & 1979 & 30,3 & 9,9 & 10,1 & 20,8 \\
\hline & 1987 & 30,1 & 11,8 & 10,6 & 20,6 \\
\hline & 2004 & 33,7 & 17,3 & 11,2 & 25,0 \\
\hline & 2019 & 37,2 & 25,2 & 14,2 & 31,2 \\
\hline \multirow{4}{*}{$\begin{array}{l}\overline{\mathrm{H}} \\
{[\mathrm{m}]}\end{array}$} & 1979 & - & - & - & - \\
\hline & 1987 & 19,3 & 10,5 & 9,8 & 14,7 \\
\hline & 2004 & 20,9 & 13,2 & 9,9 & 16,7 \\
\hline & 2019 & 22,1 & 18,0 & 10,9 & 19,5 \\
\hline \multirow{4}{*}{$\begin{array}{l}\overline{\mathrm{G}} \\
{\left[\mathrm{m}^{2}\right]}\end{array}$} & 1979 & 0,085 & 0,008 & 0,009 & 0,049 \\
\hline & 1987 & 0,086 & 0,012 & 0,010 & 0,048 \\
\hline & 2004 & 0,108 & 0,027 & 0,013 & 0,068 \\
\hline & 2019 & 0,131 & 0,058 & 0,022 & 0,100 \\
\hline \multirow{4}{*}{$\begin{array}{l}\bar{V} \\
{\left[\mathrm{~m}^{3}\right]}\end{array}$} & 1979 & 0,82 & 0,03 & 0,03 & 0,45 \\
\hline & 1987 & 0,94 & 0,07 & 0,06 & 0,50 \\
\hline & 2004 & 1,26 & 0,23 & 0,10 & 0,76 \\
\hline & 2019 & 1,63 & 0,67 & 0,20 & 1,22 \\
\hline
\end{tabular}

Objaśnienia (Explanations): ${ }^{1}$ - z wiązem górskim (with mountain elm), ${ }^{2}-$ dąb szypułkowy i bezszypułkowy (pedunculate and sessile oak), dane o złomach żywych (data on living snags). Średnie cech biometrycznych bez złomów żywych (average biometric characters, without living snags). N - liczba drzew (number of trees), G - powierzchnia przekroju (basal area), V - miąższość (volume), D - pierśnica (diameter at breast heigh), H - wysokość (height). 
Przeciętna wysokość drzew w badanych terminach także wzrosła: olszy czarnej i wiązu górskiego - o 2,8 m (14,5\%), dębów - aż o 7,6 m (72,1\%), wszystkich drzew w drzewostanie - o 4,8 m (32,5\%) (Tab. 1).

Zasobność badanego drzewostanu nie jest wysoka i odpowiadała w poszczególnych terminach pomiarowych III, II, II, II (Szwappach) lub IV, IV, III, II (Tiurin) klasie bonitacji siedliska. Największy udział miąższościowy miały we wszystkich terminach pomiarowych olsza czarna i wiąz górski, których zasobność wzrosła o $225,05 \mathrm{~m}^{3} / \mathrm{ha}(93,7 \%)$. Zasobność dębów wzrosła o 42,44 m³/ha (aż o 997,2\%), a całego drzewostanu o $279,37 \mathrm{~m}^{3} / \mathrm{ha}$ $(212,6 \%)$ (Tab. 1). Przeciętna miąższość olch czarnych i wiązów górskich w drzewostanie wzrosła o $0,81 \mathrm{~m}^{3}(98,5 \%)$. Bardzo duży był wzrost średniej miąższości dębów - o 0,64 $\mathrm{m}^{3}$, czyli ponad 23-krotny. Dla całego drzewostanu średnia miąższość drzew wzrosła o $0,77 \mathrm{~m}^{3}$ $(272,8 \%)$ (Tab. 1).

Omawiając strukturę drzewostanu, należy zwrócić uwagę na obecność w 2004 r. licznych złomów żywych, w tym głównie tych, które były skutkiem huraganowych wiatrów z 2001 r. Odnotowano w sumie 25 takich drzew, w tym 23 olsze czarne i 2 dęby (w przeliczeniu na 1 ha), o łącznej miąższości 17,58 m³/ha (Tab. 1), co stanowiło 4,5\% miąższości nieuszkodzonych drzew żywych.

\section{Martwe drzewa}

\section{Drzewa martwe stojace}

Martwe drzewa stojące nie miały istotnego udziału w strukturze drzewostanu olszowego. Martwe drzewa w rezerwacie były kilkakrotnie usuwane z drzewostanu, bez tych zabiegów liczba martwych drzew byłaby większa. Omawiana grupa drzew reprezentowana była głównie przez złomy. Całe drzewa martwe występowały wyłącznie w 1987 r., zaś w 2004 r. współdominowały ilościowo i objętościowo (Tab. 2).

W badanym drzewostanie stwierdzono w sumie martwe osobniki stojące pięciu gatunków drzew i krzewów. Najliczniejszym gatunkiem w drzewostanie były dęby, a następnie olsza czarna i jarzębina. W latach 1987-2019 liczebność drzew uległa zmniejszeniu w przypadku olszy czarnej i wiązu górskiego o 5 drzew (35,7\%), natomiast zwiększeniu w przypadku dębów - o 13 drzew (360,0\%) i całego drzewostanu - o 46 drzew $(1020,0 \%)$ (Tab. 2).

Rozkład grubości wszystkich drzew martwych stojących był lewoskośny (Ryc. 3), z największą liczbą drzew w najniższych stopniach grubości. Powierzchnia przekroju pierśnicowego drzew uległa zmniejszeniu w przypadku olszy czarnej i wiązu górskiego o $0,21 \mathrm{~m}^{2} /$ ha $(41,2 \%)$, a zwiększeniu w przypadku dębów - o $0,15 \mathrm{~m}^{2} / \mathrm{ha}(772,7 \%)$ i całego drzewostanu - o $0,64 \mathrm{~m}^{2} /$ ha (ponad 30-krotnie) (Tab. 2). Średnia pierśnica olszy czarnej i wiązu górskiego zmniejszyła się o $1,8 \mathrm{~cm}(9,1 \%)$, natomiast dębów wzrosła o $3,3 \mathrm{~cm}$ $(45,5 \%)$. Tak samo wzrosła średnia grubość wszystkich drzew w drzewostanie - o $4,4 \mathrm{~cm}$ $(60,8 \%)$. Średnia powierzchnia przekroju pierśnicowego pni olszy czarnej i wiązu górskiego zmniejszyła się nieznacznie $\left(0,002 \mathrm{~m}^{2} / \mathrm{ha} ; 5,5 \%\right)$, natomiast zwiększyła się znacznie w przypadku dębów $\left(0,005 \mathrm{~m}^{2} / \mathrm{ha} ; 225,0 \%\right)$ i wszystkich drzew drzewostanu $\left(0,01 \mathrm{~m}^{2} / \mathrm{ha}\right.$; 325,0\%) (Tab. 3). 


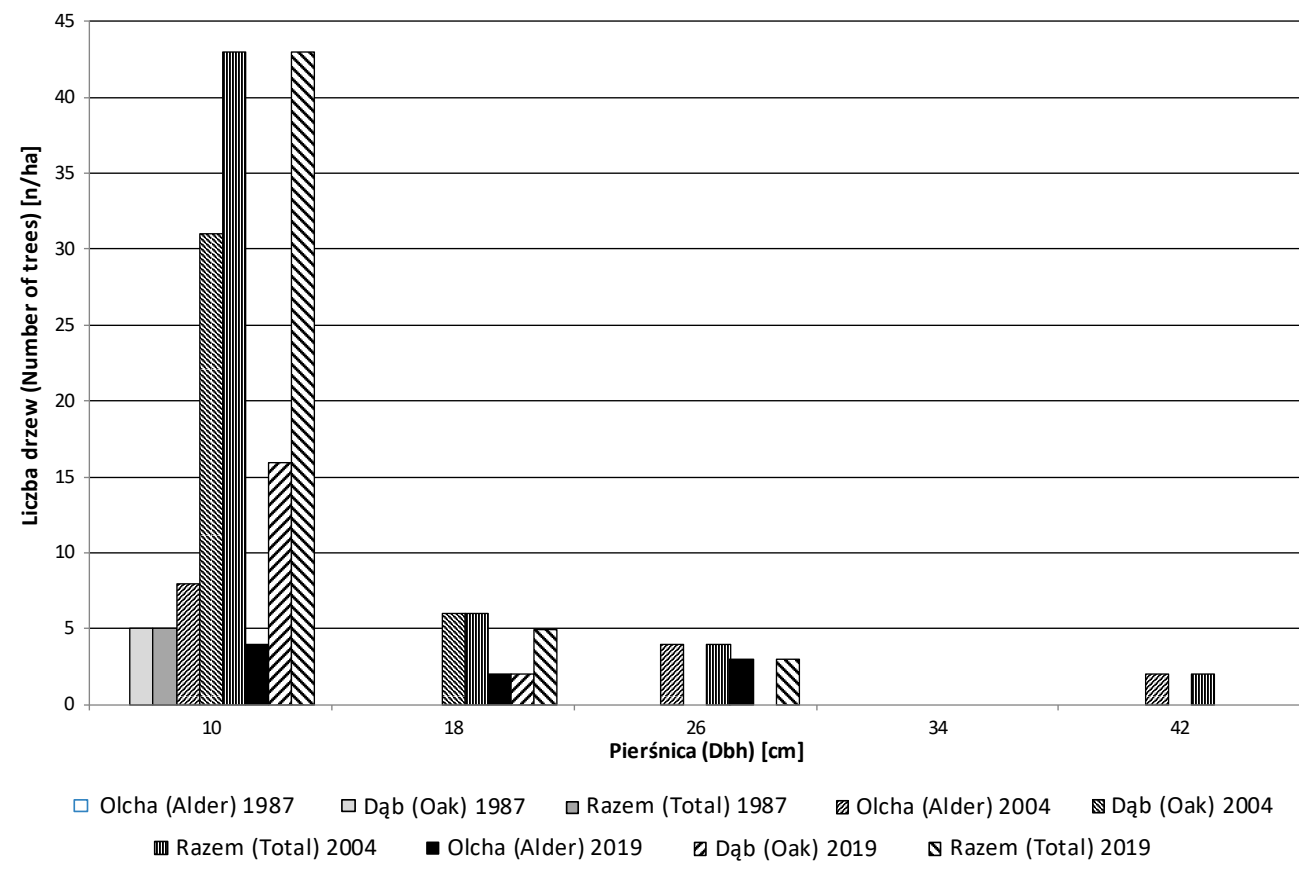

Ryc. 3. Rozkład pierśnic drzew martwych stojących w badanym drzewostanie jesionowo-olszowym w rezerwacie przyrody „Ochojec” w latach 1979-2019

Fig. 3. Diameter at breast height distribution (Dbh) of standing dead trees in the studied ash-alder forest stand in the Ochojec Nature Reserve in 1979-2019

Przeciętna wysokość drzew w badanych terminach zmniejszyła się nieznacznie: olszy czarnej i wiązu górskiego - o 1,6 m (13,9\%), dębów - o 1,9 m (25,4\%) i wszystkich drzew drzewostanu - o 0,6 m (7,9\%) (Tab. 3).

Zasobność badanego drzewostanu w drzewa martwe stojące nie była wysoka. Największy udział miąższościowy miały olsza czarna i wiąz górski, a zdecydowanie mniejszy był udział dębów (Tab. 2). Miąższość olszy czarnej i wiązu górskiego zmniejszyła się o $3,14 \mathrm{~m}^{3} /$ ha $(45,3 \%)$, natomiast zwiększyła w przypadku dębów o $0,78 \mathrm{~m}^{3} / \mathrm{ha}(1560,0 \%)$ i całego drzewostanu - o 4,37 m³/ha $(8840,0 \%)$. Przeciętna miąższość olsz czarnych i wiązów górskich w drzewostanie zmniejszyła się o $0,11 \mathrm{~m}^{3} /$ ha $(27,4 \%)$, natomiast wzrosła w przypadku dębów - o $0,03 \mathrm{~m}^{3} / \mathrm{ha}(430,0 \%)$ i wszystkich drzew w drzewostanie - o $0,08 \mathrm{~m}^{3} / \mathrm{ha}$ $(870,0 \%)$ (Tab. 3).

\section{Drzewa martwe leżace}

Martwe drzewa leżące miały znacząco większy udział niż stojące w zasobach drzew martwych badanego fragmentu lasu, gdzie w latach 1987-2004 i 2004-2019 powalone zostały osobniki należące do 12 gatunków drzew i krzewów. Najliczniejszym gatunkiem były dęby, a następnie jarzębina i olsza czarna. Liczebność drzew martwych leżących olszy czarnej i wiązu górskiego wzrosła o 21 drzew (210,5\%), dębów - o 20 drzew (131,7\%), a całego drzewostanu - o 27 (118,4\%) (Tab. 2). 
Tabela 2. Zmiany cech struktury drzew martwych w badanym drzewostanie jesionowo-olszowym w rezerwacie przyrody „Ochojec” w latach 1979-2019

Table 2. Structural changes of dead trees in the studied ash-alder forest stand in the Ochojec Nature Reserve in 1979-2019

\begin{tabular}{|c|c|c|c|c|c|}
\hline \multirow{2}{*}{$\begin{array}{l}\text { Cecha } \\
\text { (Characteristic) }\end{array}$} & \multirow{2}{*}{$\begin{array}{l}\text { Rok } \\
\text { (Year) }\end{array}$} & \multicolumn{3}{|c|}{ Gatunek (Species) } & \multirow{2}{*}{$\begin{array}{l}\text { Razem } \\
\text { (Total) }\end{array}$} \\
\hline & & $\begin{array}{l}\text { Olcha }^{1} \\
\text { (Alder) }\end{array}$ & $\begin{array}{l}\mathrm{Daqb}^{2} \\
(\text { Oak) }\end{array}$ & $\begin{array}{l}\text { Inne } \\
\text { (Other) }\end{array}$ & \\
\hline \multicolumn{6}{|c|}{ Drzewa martwe stojące - całe (Standing dead trees - whole) } \\
\hline \multirow{3}{*}{$\begin{array}{l}\mathrm{N} \\
{[\mathrm{n} / \mathrm{ha}]}\end{array}$} & 1987 & - & 5 & - & 5 \\
\hline & 2004 & 5 & 21 & 2 & 28 \\
\hline & 2019 & - & - & 5 & 5 \\
\hline \multirow{3}{*}{$\begin{array}{l}\mathrm{G} \\
{\left[\mathrm{m}^{2} / \mathrm{ha}\right]}\end{array}$} & 1987 & - & 0,022 & - & 0,022 \\
\hline & 2004 & 0,247 & 0,232 & 0,009 & 0,488 \\
\hline & 2019 & - & - & 0,032 & 0,032 \\
\hline \multirow{3}{*}{$\begin{array}{l}\mathrm{V} \\
{\left[\mathrm{m}^{3} / \mathrm{ha}\right]}\end{array}$} & 1987 & - & 0,05 & - & 0,05 \\
\hline & 2004 & 3,21 & 0,93 & 0,02 & 4,16 \\
\hline & 2019 & - & - & 0,05 & 0,05 \\
\hline \multicolumn{6}{|c|}{ Drzewa martwe stojące - złomy (Standing dead trees - snags) } \\
\hline \multirow{3}{*}{$\begin{array}{l}\mathrm{N} \\
{[\mathrm{n} / \mathrm{ha}]}\end{array}$} & 1987 & - & - & - & - \\
\hline & 2004 & 9 & 16 & 2 & 27 \\
\hline & 2019 & 9 & 18 & 19 & 46 \\
\hline \multirow{3}{*}{$\begin{array}{l}\mathrm{G} \\
{\left[\mathrm{m}^{2} / \mathrm{ha}\right]}\end{array}$} & 1987 & - & - & - & - \\
\hline & 2004 & 0,260 & 0,132 & 0,008 & 0,400 \\
\hline & 2019 & 0,298 & 0,170 & 0,163 & 0,631 \\
\hline \multirow{3}{*}{$\begin{array}{l}\mathrm{V} \\
{\left[\mathrm{m}^{3} / \mathrm{ha}\right]}\end{array}$} & 1987 & - & - & - & - \\
\hline & 2004 & 2,53 & 0,58 & 0,01 & 3,12 \\
\hline & 2019 & 2,60 & 0,83 & 0,94 & 4,37 \\
\hline \multicolumn{6}{|c|}{ Drzewa martwe stojące - razem (Standing dead trees - total) } \\
\hline \multirow{3}{*}{$\begin{array}{l}\mathrm{N} \\
{[\mathrm{n} / \mathrm{ha}]}\end{array}$} & 1987 & - & 5 & - & 5 \\
\hline & 2004 & 14 & 37 & 4 & 55 \\
\hline & 2019 & 9 & 18 & 24 & 51 \\
\hline \multirow{3}{*}{$\begin{array}{l}\mathrm{G} \\
{\left[\mathrm{m}^{2} / \mathrm{ha}\right]}\end{array}$} & 1987 & - & 0,022 & - & 0,022 \\
\hline & 2004 & 0,507 & 0,364 & 0,017 & 0,888 \\
\hline & 2019 & 0,298 & 0,170 & 0,195 & 0,663 \\
\hline \multirow{3}{*}{$\begin{array}{l}\mathrm{V} \\
{\left[\mathrm{m}^{3} / \mathrm{ha}\right]}\end{array}$} & 1987 & - & 0,05 & - & 0,05 \\
\hline & 2004 & 5,74 & 1,51 & 0,03 & 7,28 \\
\hline & 2019 & 2,60 & 0,83 & 0,99 & 4,42 \\
\hline
\end{tabular}

Drzewa martwe leżące (Lying dead trees)

\begin{tabular}{l|c|c|c|c|c}
\hline $\mathrm{N}$ & 2004 & 19 & 63 & 65 & 147 \\
{$[\mathrm{n} / \mathrm{ha}]$} & 2019 & 40 & 83 & 51 & 174 \\
\hline $\mathrm{G}$ & 2004 & 0,917 & 0,462 & 0,539 & 1,918 \\
{$\left[\mathrm{~m}^{2} / \mathrm{ha}\right]$} & 2019 & 1,754 & 1,204 & 0,392 & 3,350 \\
\hline $\mathrm{V}$ & 2004 & 11,25 & 1,84 & 2,77 & 15,86 \\
{$\left[\mathrm{~m}^{3} / \mathrm{ha}\right]$} & 2019 & 16,56 & 6,46 & 1,80 & 24,82 \\
\hline
\end{tabular}

Objaśnienia (Explanations): ${ }^{1}$ - z wiązem górskim (with mountain elm), ${ }^{2}-$ dąb szypułkowy i bezszypułkowy (pedunculate and sessile oak). N, G, V - jak w tabeli 1 (as in table 1). 
Tabela 3. Zmiany średnich cech biometrycznych martwych drzew w badanym drzewostanie jesionowo-olszowym w rezerwacie przyrody „Ochojec” w latach 1979-2019

Table 3. Changes in average biometric characters of dead trees in the studied ash-alder forest stand in the Ochojec Nature Reserve in 1979-2019

\begin{tabular}{|c|c|c|c|c|c|c|c|c|c|c|c|c|c|}
\hline \multirow{2}{*}{$\begin{array}{l}\text { Gatunek } \\
\text { (Species) }\end{array}$} & \multirow{2}{*}{$\begin{array}{c}\text { Rok } \\
\text { (Year) }\end{array}$} & \multicolumn{12}{|c|}{ Cecha (Character) } \\
\hline & & $\begin{array}{c}\mathrm{D} \\
{[\mathrm{cm}]}\end{array}$ & $\begin{array}{c}\mathrm{SD} \\
{[\mathrm{cm}]}\end{array}$ & $\begin{array}{l}\text { Vzm } \\
{[\%]}\end{array}$ & $\begin{array}{c}\mathrm{H} \\
{[\mathrm{m}]}\end{array}$ & $\begin{array}{l}\text { SD } \\
{[\mathrm{m}]}\end{array}$ & $\begin{array}{l}\text { Vzm } \\
{[\%]}\end{array}$ & $\begin{array}{c}\mathrm{G} \\
{\left[\mathrm{m}^{2}\right]}\end{array}$ & $\begin{array}{c}\mathrm{SD} \\
{\left[\mathrm{m}^{2}\right]}\end{array}$ & $\begin{array}{l}\text { Vzm } \\
{[\%]}\end{array}$ & $\begin{array}{c}\mathrm{V} \\
{\left[\mathrm{m}^{3}\right]}\end{array}$ & $\begin{array}{l}\mathrm{SD} \\
{\left[\mathrm{m}^{3}\right]}\end{array}$ & $\begin{array}{l}\text { Vzm } \\
{[\%]}\end{array}$ \\
\hline \multicolumn{14}{|c|}{ Drzewa martwe stojące - całe (Standing dead trees - whole) } \\
\hline \multirow{3}{*}{$\begin{array}{l}\text { Olcha }{ }^{1} \\
\text { (Alder) }\end{array}$} & 1987 & - & - & - & - & - & - & - & - & - & - & - & - \\
\hline & 2004 & 18,6 & 19,29 & 103,5 & 13,3 & 12,29 & 92,2 & 0,047 & 0,074 & 156,6 & 0,61 & 1,04 & 170,4 \\
\hline & 2019 & - & - & - & - & - & - & - & - & - & - & - & - \\
\hline \multirow{3}{*}{$\begin{array}{l}\mathrm{Dacb}^{2} \\
\text { (Oak) }\end{array}$} & 1987 & 7,3 & 0,63 & 8,7 & 7,3 & 0,58 & 7,9 & 0,004 & 0,001 & 13,3 & 0,01 & 0,00 & 0,0 \\
\hline & 2004 & 11,5 & 2,96 & 25,7 & 9,2 & 1,17 & 12,7 & 0,011 & 0,006 & 51,3 & 0,04 & 0,03 & 73,8 \\
\hline & 2019 & - & - & - & - & - & - & - & - & - & - & - & - \\
\hline \multirow{3}{*}{$\begin{array}{l}\text { Inne } \\
\text { (Others) }\end{array}$} & 1987 & - & - & - & - & - & - & - & - & - & - & - & - \\
\hline & 2004 & 8,0 & 0,00 & 0,0 & 7,0 & 0,00 & 0,0 & 0,005 & 0,000 & 0,0 & 0,01 & 0,00 & 0,0 \\
\hline & 2019 & 8,6 & 1,62 & 18,7 & 6,5 & 0,87 & 13,3 & 0,006 & 0,002 & 33,3 & 0,01 & 0,00 & 0,0 \\
\hline \multirow{3}{*}{$\begin{array}{l}\text { Razem } \\
\text { (Total) }\end{array}$} & 1987 & 7,3 & 0,63 & 8,7 & 7,3 & 0,58 & 7,9 & 0,004 & 0,001 & 13,3 & 0,01 & 0,00 & 0,0 \\
\hline & 2004 & 12,6 & 8,10 & 64,1 & 9,9 & 4,94 & 50,1 & 0,017 & 0,031 & 178,7 & 0,15 & 0,44 & 299,9 \\
\hline & 2019 & 8,6 & 1,62 & 18,7 & 6,5 & 0,87 & 13,3 & 0,006 & 0,002 & 33,3 & 0,01 & 0,00 & 0,0 \\
\hline \multicolumn{14}{|c|}{ Drzewa martwe stojące - złomy (Standing dead trees - snags) } \\
\hline \multirow{3}{*}{$\begin{array}{l}\text { Olcha }^{1} \\
\text { (Alder) }\end{array}$} & 1987 & - & - & - & - & - & - & - & - & - & - & - & - \\
\hline & 2004 & 22,4 & 13,23 & 59,0 & 10,6 & 7,72 & 73,0 & 0,030 & 0,018 & 62,7 & 0,29 & 0,32 & 109,8 \\
\hline & 2019 & 19,2 & 9,34 & 48,7 & 10,0 & 7,19 & 71,9 & 0,034 & 0,027 & 79,4 & 0,30 & 0,29 & 98,8 \\
\hline \multirow{3}{*}{$\begin{array}{l}\mathrm{Dacb}^{2} \\
(\mathrm{Oak})\end{array}$} & 1987 & - & - & - & - & - & - & - & - & - & - & - & - \\
\hline & 2004 & 10,1 & 2,81 & 27,8 & 6,5 & 2,10 & 32,3 & 0,008 & 0,005 & 55,0 & 0,04 & 0,02 & 61,4 \\
\hline & 2019 & 10,8 & 2,51 & 23,2 & 5,7 & 1,68 & 29,6 & 0,010 & 0,004 & 45,3 & 0,05 & 0,03 & 71,8 \\
\hline \multirow{3}{*}{$\begin{array}{l}\text { Inne } \\
\text { (Others) }\end{array}$} & 1987 & - & - & - & - & - & - & - & - & - & - & - & - \\
\hline & 2004 & 8,0 & 0,00 & 0,0 & 5,0 & 0,00 & 0,0 & 0,005 & 0.000 & 0,0 & 0,02 & 0,00 & 0,0 \\
\hline & 2019 & 9,9 & 3,79 & 38,2 & 6,3 & 4,39 & 69,6 & 0,008 & 0,007 & 78,9 & 0,05 & 0,06 & 130,8 \\
\hline \multirow{3}{*}{$\begin{array}{l}\text { Razem } \\
\text { (Total) }\end{array}$} & 1987 & - & - & - & - & - & - & - & - & - & - & - & - \\
\hline & 2004 & 14,0 & 9,61 & 68,4 & 7,8 & 4,89 & 63,0 & 0,015 & 0,015 & 98,1 & 0,12 & 0,48 & 401,7 \\
\hline & 2019 & 12,0 & 5,89 & 48,9 & 6,8 & 4,44 & 65,5 & 0,014 & 0,016 & 112,4 & 0,10 & 0,16 & 167,9 \\
\hline
\end{tabular}

Drzewa martwe stojące - razem (Standing dead trees - total)

\begin{tabular}{l|c|c|c|c|c|c|c|c|c|c|c|c|c}
\hline Olcha $^{1}$ & 1987 & - & - & - & - & - & - & - & - & - & - & - & - \\
(Alder) & 2004 & 21,0 & 14,50 & 69,0 & 11,6 & 8,90 & 76,7 & 0,036 & 0,043 & 118,3 & 0,41 & 0,63 & 153,5 \\
& 2019 & 19,2 & 9,34 & 48,7 & 10,0 & 7,19 & 71,9 & 0,034 & 0,027 & 79,4 & 0,30 & 0,29 & 98,8 \\
\hline \multirow{2}{*}{$\begin{array}{l}\text { Dąb } \\
\text { (Oak) }\end{array}$} & 1987 & 7,3 & 0,63 & 8,7 & 7,3 & 0,58 & 7,9 & 0,004 & 0,001 & 13,3 & 0,01 & 0,00 & 0,0 \\
& 2004 & 10,9 & 2,92 & 26,7 & 8,1 & 2,10 & 26,1 & 0,010 & 0,005 & 52,7 & 0,04 & 0,03 & 69,3 \\
& 2019 & 10,6 & 2,55 & 24,1 & 5,5 & 1,64 & 30,0 & 0,009 & 0,004 & 48,2 & 0,04 & 0,03 & 77,0 \\
\hline \multirow{2}{*}{ Inne } & 1987 & - & - & - & - & - & - & - & - & - & - & - & - \\
(Others) & 2004 & 7,9 & 0,07 & 0,1 & 6,0 & 1,41 & 23,6 & 0,005 & 0,000 & 0,0 & 0,01 & 0,01 & 44,7 \\
& 2019 & 9,6 & 3,43 & 35,5 & 6,4 & 3,87 & 60,9 & 0,008 & 0,006 & 75,6 & 0,04 & 0,06 & 144,1 \\
\hline \multirow{2}{*}{ Razem } & 1987 & 7,3 & 0,63 & 8,7 & 7,3 & 0,58 & 7,9 & 0,004 & 0,001 & 13,3 & 0,01 & 0,00 & 0,0 \\
(Total) & 2004 & 13,3 & 8,74 & 65,6 & 8,8 & 4,95 & 56,0 & 0,016 & 0,024 & 147,7 & 0,13 & 0,35 & 257,9 \\
& 2019 & 11,7 & 5,68 & 48,6 & 6,7 & 4,20 & 62,2 & 0,013 & 0,015 & 114,5 & 0,09 & 0,15 & 177,5 \\
\hline
\end{tabular}


Tabela 3. Kontynuacja - Table 3. Continued

\begin{tabular}{l|c|c|c|c|c|c|c|c|c|c|c|c|c}
\hline \hline \multirow{2}{*}{$\begin{array}{l}\text { Gatunek } \\
\text { (Species) }\end{array}$} & \multirow{2}{*}{$\begin{array}{c}\text { Rok } \\
\text { (Year) }\end{array}$} & $\begin{array}{c}\mathrm{D} \\
{[\mathrm{cm}]}\end{array}$ & $\begin{array}{c}\mathrm{SD} \\
{[\mathrm{cm}]}\end{array}$ & $\begin{array}{c}\text { Vzm } \\
{[\%]}\end{array}$ & $\begin{array}{c}\mathrm{H} \\
{[\mathrm{m}]}\end{array}$ & $\begin{array}{c}\mathrm{SD} \\
{[\mathrm{m}]}\end{array}$ & $\begin{array}{c}\text { Vzm } \\
{[\%]}\end{array}$ & $\begin{array}{c}\mathrm{G} \\
{\left[\mathrm{m}^{2}\right]}\end{array}$ & $\begin{array}{c}\text { SD } \\
{\left[\mathrm{m}^{2}\right]}\end{array}$ & $\begin{array}{c}\text { Vzm } \\
{[\%]}\end{array}$ & $\begin{array}{c}\mathrm{V} \\
{\left[\mathrm{m}^{3}\right]}\end{array}$ & $\begin{array}{c}\text { SD } \\
{\left[\mathrm{m}^{3}\right]}\end{array}$ & $\begin{array}{c}\text { Vzm } \\
{[\%]}\end{array}$ \\
\hline
\end{tabular}

Drzewa martwe leżące (Lying dead trees)

\begin{tabular}{l|c|c|c|c|c|c|c|c|c|c|c|c|c}
\hline Olcha $^{1}$ & 2004 & 21,2 & 17,36 & 81,7 & 13,9 & 7,25 & 52,0 & 0,057 & 0,095 & 167,0 & 0,58 & 1,14 & 195,2 \\
(Alder) & 2019 & 21,1 & 13,25 & 62,9 & 11,2 & 6,75 & 60,2 & 0,048 & 0,057 & 118,9 & 0,41 & 0,72 & 175,9 \\
\hline Dąb $^{2}$ & 2004 & 9,3 & 2,45 & 26,3 & 8,8 & 2,65 & 29,9 & 0,007 & 0,004 & 55,9 & 0,03 & 0,03 & 114,8 \\
(Oak) & 2019 & 12,8 & 4,35 & 34,1 & 9,9 & 3,88 & 39,1 & 0,014 & 0,010 & 72,6 & 0,08 & 0,09 & 119,6 \\
\hline Inne & 2004 & 10,1 & 3,44 & 34,1 & 9,0 & 3,74 & 41,5 & 0,009 & 0,007 & 79,9 & 0,04 & 0,07 & 167,7 \\
(Others) & 2019 & 9,2 & 3,42 & 37,0 & 8,5 & 3,42 & 40,3 & 0,008 & 0,008 & 101,3 & 0,03 & 0,08 & 241,2 \\
\hline Razem & 2004 & 11,2 & 7,71 & 68,7 & 9,6 & 4,27 & 44,6 & 0,014 & 0,037 & 257,8 & 0,11 & 0,44 & 408,3 \\
(Total) & 2019 & 13,6 & 8,40 & 61,5 & 9,8 & 4,65 & 47,4 & 0,020 & 0,032 & 160,6 & 0,14 & 0,38 & 267,0 \\
\hline
\end{tabular}

Objaśnienia (Explanations): ${ }^{1}$ - z wiązem górskim (with mountain elm), ${ }^{2}$ - dąb szypułkowy i bezszypułkowy (pedunculate and sessile oak). D, H, G, V - jak w tabeli 1(as in table 1). SD - odchylenie standardowe (standard deviation), Vzm - współczynnik zmienności (coefficient of variation).

Należy dodać, że w obu analizowanych okresach udział drzew faktycznie martwych (pomierzonych jako drzewa martwe stojące w latach 2004 i 2019) wynosił w 2004 r. 3,4\% liczby wszystkich drzew, które ubyły w okresie 1987-2004, i 0,3\% miąższości ich grubizny, natomiast w 2019 r. już odpowiednio 39,1\% i 41,0\% dla drzew, które ubyły w okresie 2004-2019.

Rozkład grubości wszystkich drzew martwych leżących był lewoskośny (Ryc. 4), z największą liczbą drzew w najniższych stopniach grubości. Powierzchnia przekroju pierśnicowego drzew martwych leżących zwiększyła się: olszy czarnej i wiązu górskiego o $0,84 \mathrm{~m}^{2} / \mathrm{ha}$ (191,3\%), dębów - o 0,74 $\mathrm{m}^{2} / \mathrm{ha}(260,6 \%)$, a całego drzewostanu - o $1,43 \mathrm{~m} / \mathrm{ha}(174,7 \%)$. Średnia pierśnica olch czarnych i wiązów górskich nieznacznie się zmniejszyła - o $0,2 \mathrm{~cm}$ (o 0,9\%), zwiększyła się natomiast w przypadku dębów - o 3,4 cm (136,6\%) i wszystkich drzew w drzewostanie - o $2,4 \mathrm{~cm}(121,5 \%)$. Średnia powierzchnia przekroju pierśnicowego pni olszy czarnej i wiązu górskiego zmniejszyła się o $0,009 \mathrm{~m}^{2} / \mathrm{ha}(15,8 \%)$, natomiast dębów i wszystkich drzew w drzewostanie zwiększyła się, odpowiednio o $0,007 \mathrm{~m}^{2} / \mathrm{ha}$ $(200,0 \%)$ i $0,006 \mathrm{~m}^{2} / \mathrm{ha}(102,3 \%)$ (Tab. 3).

Przeciętna długość ${ }^{3}$ drzew leżących olszy czarnej i wiązu górskiego zmniejszyła się o 2,7 m (80,4\%), natomiast zwiększyła się w przypadku dębów - o 1,1 m (112,3\%) i wszystkich drzew w drzewostanie - o 0,2 m (102,3\%) (Tab. 3).

Zasobność badanego drzewostanu w drzewa martwe leżące jest wysoka. Największy udział miąższościowy ma olsza czarna i wiąz górski, zdecydowanie mniejszy był udział dębów i pozostałych gatunków (Tab. 2). Miąższość olszy czarnej i wiązu górskiego wzrosła w analizowanym okresie o $5,31 \mathrm{~m}^{3} / \mathrm{ha}(147,2 \%)$, dębów - o 4,62 $\mathrm{m}^{3} / \mathrm{ha}(351,1 \%)$, a całego drzewostanu - o 8,96 m³/ha (156,5\%). Średnia miąższość olch czarnych i wiązów

\footnotetext{
3 Faktycznie nie jest to długość, lecz pomierzona wysokość drzew stojących.
} 


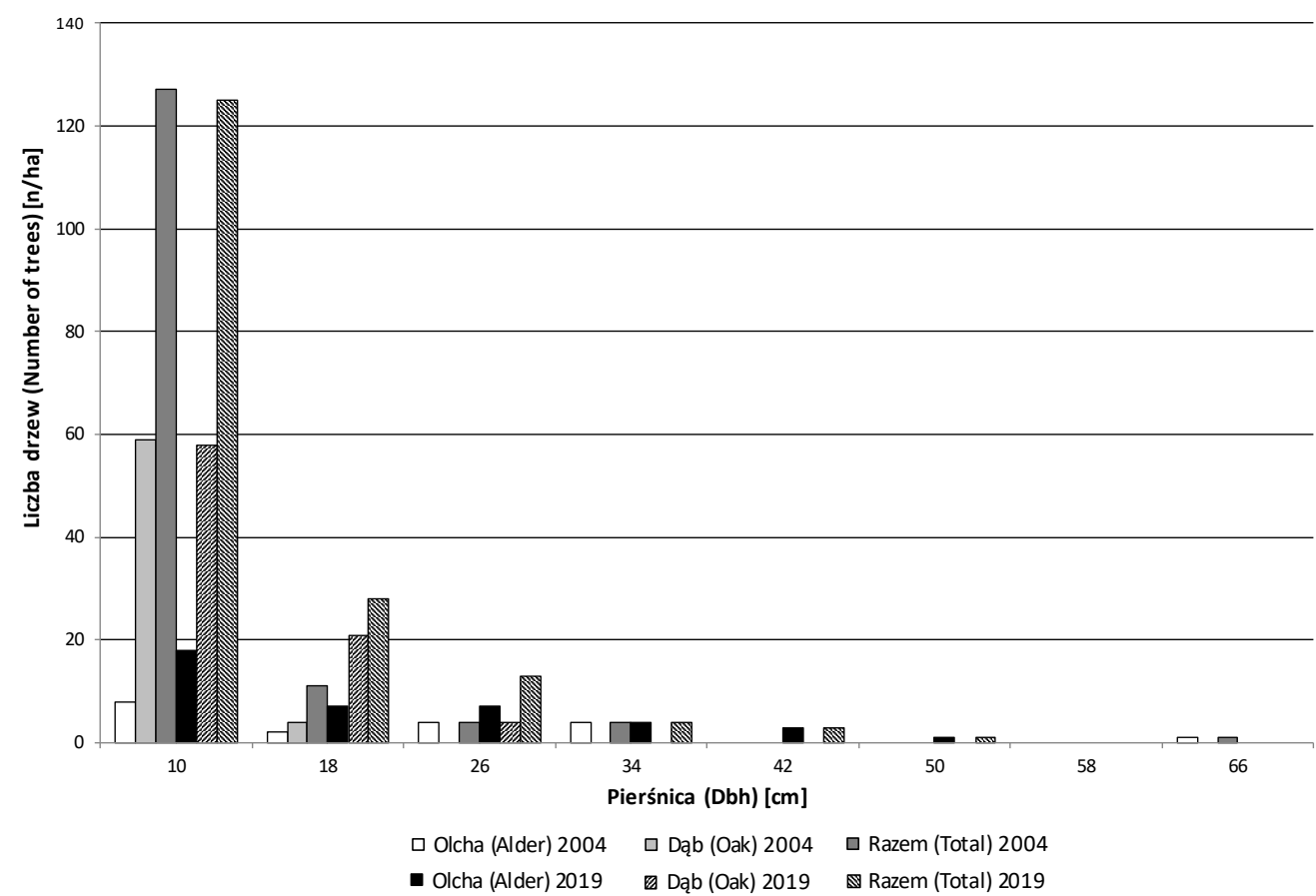

Ryc. 4. Rozkład pierśnic drzew martwych leżących w badanym drzewostanie jesionowo-olszowym w rezerwacie przyrody „Ochojec” w latach 1979-2019

Fig. 4. Diameter at breast height (Dbh) distribution of lying dead trees in the studied ash-alder forest stand in the Ochojec Nature Reserve in 1979-2019

górskich w drzewostanie zmniejszyła się o $0,17 \mathrm{~m}^{3} / \mathrm{ha}$, zwiększyła się natomiast w przypadku dębów - o $0,05 \mathrm{~m}^{3} / \mathrm{ha}(269,0 \%)$ i drzew w całym drzewostanie - o $0,03 \mathrm{~m}^{3} / \mathrm{ha}$ $(132,4 \%)$ (Tab. 3).

\section{DYSKUSJA}

Drzewa martwe nie odgrywają współcześnie większej roli w strukturze badanego drzewostanu łęgu jesionowo-olszowego. Liczebność ogółem drzew martwych stojących w 1987 r. stanowiła 0,8\% liczebności drzew żywych, a w latach następnych odpowiednio 10,2\% i 11,8\% (Tab. 1, 2). Dla olszy czarnej i wiązu górskiego odsetek ten w 2004 r. wynosił 4,9\%, a w 2019 r. - 2,1\%. O wiele większy był on dla martwych dębów - 2,4\% w 1987 r., 29,6\% w 2004 r. i 27,7\% w 2019 r. Jeszcze większy odsetek stanowiły w 2019 r. martwe jarzębiny $-56,8 \%$. Miąższość ogółem drzew martwych stojących w 1987 r. stanowiła 0,02\% miąższości ogółem drzew żywych, w 2004 r. - 2,0\% a w 2019 r. - 0,6\%. Największy był odsetek dla olszy czarnej i wiązu górskiego: 1,9\% w 2004 r. i 0,4\% w 2019 r. (Tab. 1, 2). Drzewa martwe stojące charakteryzowały się mniejszymi wymiarami niż drzewa żywe. Dla średniej pierśnicy wymiar ten był mniejszy o 48,6\% dla olszy czarnej i wiązu górskiego, $58,0 \%$ dla dębów i 62,6\% dla wszystkich drzew w drzewostanie. Dla średniej wysokości wymiar ten był mniejszy o 54,8\% dla olszy czarnej i wiązu górskiego, 69,7\% dla dębów 
i 65,4\% dla wszystkich drzew w drzewostanie. Jeszcze mniejsza była średnia zasobność martwych drzew stojących: o 81,7\% dla olszy czarnej i wiązu górskiego, 90,6\% dla dębów i 92,9\% dla wszystkich drzew w drzewostanie.

Zasobność martwych drzew stojących badanej powierzchni jest obecnie większa od ich zasobności w lasach gospodarczych RDLP w Katowicach, która wynosiła 3,8 $\mathrm{m}^{3} / \mathrm{ha}$ grubizny brutto, i od zasobności stwierdzonej w drzewostanach Lasów Państwowych, równej $3,7 \mathrm{~m}^{3} /$ ha grubizny brutto (WIELKOOBSZAROWA INWENTARYZACJA 2019). Wartość ta jest wyższa od zasobności drzew martwych stojących i złomów, zainwentaryzowanych w 2019 r. w Nadleśnictwie Katowice (ProJeKT 2020) na siedlisku olsu $\left(2,98 \mathrm{~m}^{3} / \mathrm{ha}\right)$ i mniejsza od zasobności drzew martwych stojących i złomów, stwierdzonej na siedlisku olsu jesionowego $\left(8,28 \mathrm{~m}^{3} / \mathrm{ha}\right)^{4}$. Jest ona także mniejsza od wykazanej przez GóRAK (2010) na powierzchni II, która była zlokalizowana w obrębie powierzchni badanej przez autora. Objętość posuszu stojącego i odziomków w latach $2009-2010$ wynosiła $6,04 \mathrm{~m}^{3} / \mathrm{ha}$, a posuszu wiszącego $8,70 \mathrm{~m}^{3} /$ ha (GÓRAK 2010) .

Zasobność badanego lasu łęgowego w $2004 \mathrm{r}$. w drzewa martwe stojące $\left(4,16 \mathrm{~m}^{3} / \mathrm{ha}\right)$ i złomy $\left(3,12 \mathrm{~m}^{3} / \mathrm{ha}\right)$ była zdecydowanie wyższa niż w lasach łęgowych w całej Polsce - odpowiednio $1,02 \mathrm{~m}^{3} / \mathrm{ha} \mathrm{i} 1,28 \mathrm{~m}^{3} / \mathrm{ha}$ (CZEREPKO 2008).

W ekosystemie łęgu jesionowo-olszowego znaczący jest natomiast udział martwych drzew leżących (Tab. 2). W badanym drzewostanie stwierdzono osobniki należące do 12 gatunków drzew i krzewów. Wśród nich są gatunki, które nie są już reprezentowane wśród drzew stojących (Betula pendula subsp. obscura, Frangula alnus, Picea abies, Populus tremula, Salix caprea, Sambucus nigra). Liczebność ogółem drzew martwych leżących w 2004 r. stanowiła 26,9\% liczebności drzew żywych, a w 2019 r. już 40,3\% (Tab. 1, 2). Dla olszy czarnej i wiązu górskiego odsetek ten w 2004 r. wynosił 6,6\%, a w 2019 r. już 13,5\%. O wiele większy był udział leżących martwych dębów - 50,4\% w $2004 \mathrm{r}$. i aż 127,7\% w 2019 r. Wysoki odsetek stanowiły w latach 2004 i 2019 także leżące martwe jarzębiny - odpowiednio 54,1 i 81,8\%. Miąższość ogółem drzew martwych leżących w 2004 r. stanowiła 3,9\% miąższości ogółem drzew żywych, a w 2019 r. - 4,7\%. Największy był odsetek dla olszy czarnej i wiązu górskiego: 3,0\% w 2004 r. i 3,6\% w 2019 r.

Drzewa martwe, które ubyły z drzewostanu, charakteryzowały się mniejszymi wymiarami niż drzewa żywe (Tab. 1,2). Dla średniej pierśnicy wymiar ten był mniejszy o 43,4\% dla olszy czarnej i wiązu górskiego, 48,4\% dla dębów i 56,3\% dla wszystkich drzew w drzewostanie. Dla średniej wysokości wymiar ten był mniejszy o 49,4\% dla olszy czarnej

\footnotetext{
4 Zdecydowanie niższe średnie wartości zostały stwierdzone w latach 2013-2019 w sąsiednich nadleśnictwach: Kobiór, Rudziniec, Rybnik i Siewierz na siedlisku olsu $-0,92 \mathrm{~m}^{3} / \mathrm{ha}$ i olsu jesionowego $-0,84 \mathrm{~m}^{3} / \mathrm{ha}$ (zob. elaboraty planów zamieszczone w Biuletynie Informacji Publicznej tych nadleśnictw).

$5 \mathrm{~W}$ tej pracy magisterskiej przyjęto całkowicie odmienną metodykę pomiarów i obliczeń, niż zastosowano w niniejszych badaniach i stosuje się w lasach państwowych, stąd nie można porównywać wprost przytoczonych liczb. Ponadto, metodyka nie zawiera informacji o minimalnej długości leżaniny, która podlegała pomiarowi (podano tylko minimalną grubość mierzonych drzew martwych, równą $10 \mathrm{~cm}$ ). Ze szkicu rozmieszczenia drzew na powierzchniach i zestawień tabelarycznych wynika, że do obliczeń miąższości włączono w całości zarówno drzewa (lub ich fragmenty), które należały do powierzchni, jak i drzewa, które na niej nie rosły. Ten sposób obliczeń całkowicie błędnie przedstawia więc rzeczywistą objętość martwych drzew leżących na powierzchni, obliczaną zazwyczaj zgodnie ze schematem „co pochodzi z powierzchni” lub „,o jest na powierzchni”. Wprowadzony został również termin posusz wiszący, w skład którego wliczono zarówno stojący złom, jak i złamaną, wiszącą górną część pnia.
} 
i wiązu górskiego, 45,0\% dla dębów i 49,8\% dla wszystkich drzew w drzewostanie. Jeszcze mniejsza była średnia zasobność martwych drzew leżących: o 74,8\% dla olszy czarnej i wiązu górskiego, 88,4\% dla dębów i 88,3\% dla wszystkich drzew w drzewostanie.

Całkowita zasobność miąższości drzew, które ubyły z badanego drzewostanu w latach 1987-2004 i 2004-2019, wyniosła 40,68 $\mathrm{m}^{3} / \mathrm{ha}$. Wartość ta jest zdecydowanie wyższa, niż aktualna zasobność drzew martwych leżących w lasach gospodarczych RDLP w Katowicach, która wynosiła $3,7 \mathrm{~m}^{3} /$ ha grubizny brutto oraz zasobność stwierdzona w drzewostanach Lasów Państwowych, wynosząca $3,8 \mathrm{~m}^{3} /$ ha grubizny brutto (WIELKOOBSZARowA INwENTARYZACJA 2019). Jest ona także wyższa od zasobności drzew leżących i fragmentów drzew martwych, zainwentaryzowanych w 2019 r. w Nadleśnictwie Katowice (PrOJEKT 2020) na siedlisku olsu $\left(5,34 \mathrm{~m}^{3} / \mathrm{ha}\right)$ i na siedlisku olsu jesionowego $\left(2,54 \mathrm{~m}^{3} / \mathrm{ha}\right)^{6}$. Natomiast jest ona mniejsza od objętości leżaniny wykazanej przez GóRAK (2010) na powierzchni II $-48,84 \mathrm{~m}^{3} / \mathrm{ha}$. Wartość ta jest jednak zbliżona do sumarycznej objętości drzew, które ubyły z badanego drzewostanu w latach 1987-2019, co może być jednak przypadkową zbieżnością, zważywszy na zastosowane odmienne metodyki badań.

Zasobność badanego lasu łęgowego w $2004 \mathrm{r}$. w drzewa martwe leżące $\left(15,86 \mathrm{~m}^{3} / \mathrm{ha}\right)$ była zdecydowanie wyższa niż w lasach łęgowych w całej Polsce $-5,83 \mathrm{~m}^{3} / \mathrm{ha}$ (CZEREPKO 2008). Biorąc pod uwagę sumaryczną zasobność drzew martwych na badanej powierzchni w 2019 r., to uwzględniając wartości parametru Martwe drewno (łączne zasoby), ocena stanu zachowania specyficznej struktury i funkcji siedliska *91E0 dla tego parametru jest właściwa (PAWLACZYK 2010).

Zasobność rezerwatu przyrody „Ochojec” w Katowicach w martwe drzewa nie jest wysoka w porównaniu do zasobności stwierdzonej w innych rezerwatach województwa śląskiego. Średnia zasobność, wyliczona dla 15 rezerwatów (z wyjątkiem rezerwatów „Kopce” i „Skarpa Wiślicka”, dla których brak dokładnych danych ilościowych), wyniosła $136 \mathrm{~m}^{3} / \mathrm{ha}$, w tym $66 \mathrm{~m}^{3} / \mathrm{ha}$ drzew martwych stojących i $70 \mathrm{~m}^{3} / \mathrm{ha}$ drzew martwych leżących. Wartości tych jednak nie można ze sobą porównywać wprost, gdyż rezerwaty te różnią się składem gatunkowym, siedliskiem, wiekiem drzewostanów, statusem ochrony i długością czasu ochrony rezerwatowej; oczywiście należy też mieć na uwadze różnorodność zastosowanych metod badawczych. Dla podobnego pod względem siedliskowym rezerwatu przyrody „Babczyna Dolina” wyliczono (KARPIŃSKI 2017) zasobność martwych drzew na $26,25 \mathrm{~m}^{3} / \mathrm{ha}$ (wyłącznie drzewa leżące), co odpowiada zasobności wykazanej w rezerwacie przyrody „Ochojec”. Ostatnio ukazały się dwie publikacje na temat martwych drzew w rezerwatach przyrody o zbliżonych warunkach siedliskowych i drzewostanowych, położonych w województwie łódzkim: „Polesie Konstantynowskie” (PAwICKA \& Woziwoda 2011) i „Czarna Rózga" (BŁoŃSKA i in. 2019). Charakteryzowały się one znacznie większą zasobnością drzew martwych niż badany drzewostan w Katowicach. W pierwszym z nich stwierdzono łącznie $38,91 \mathrm{~m}^{3} / \mathrm{ha}$ drzew martwych, w tym $24,90 \mathrm{~m}^{3} / \mathrm{ha}$ drzew leżących i $13,62 \mathrm{~m}^{3} / \mathrm{ha}$ drzew stojących. W drugim, zasobność martwych drzew stojących wynosiła $11,78 \mathrm{~m}^{3} / \mathrm{ha}$ drzew całych i $3,35 \mathrm{~m}^{3} / \mathrm{ha}$ pniaków. Dla drzew martwych leżących zasobność ta wyniosła

\footnotetext{
6 Zdecydowanie niższe średnie wartości zostały stwierdzone w latach 2013-2019 w sąsiednich nadleśnictwach: Kobiór, Rudziniec, Rybnik i Siewierz na siedlisku olsu $-1,88 \mathrm{~m}^{3} / \mathrm{ha}$ i olsu jesionowego $-1,21 \mathrm{~m}^{3} / \mathrm{ha}$ (zob. elaboraty planów zamieszczone w Biuletynie Informacji Publicznej tych nadleśnictw).
} 
$35,45 \mathrm{~m}^{3} /$ ha drzew całych i $1,47 \mathrm{~m}^{3} /$ ha pniaków. Wartości te są zbliżone do wartość oszacowanej dla drzew martwych leżących w rezerwacie „Ochojec” dla dwóch terminów pomiarowych. Z danych podsumowanych dla chronionych naturalnych i pierwotnych lasów nadbrzeżnych w Polsce przez BuJoczKa i in. (2018) wynika, że martwych drzew w rezerwacie przyrody „Ochojec” jest znacznie mniej. W Białowieskim Parku Narodowym średnia zasobność martwych drzew stojących wynosiła $13,7 \mathrm{~m}^{3} / \mathrm{ha}$, a leżących $-123,0 \mathrm{~m}^{3} / \mathrm{ha}$, łącznie $-136,7 \mathrm{~m}^{3} / \mathrm{ha}(\mathrm{n}=6)$. Zasobność drzew martwych w naturalnych lasach mieszanych bukowo-jodłowo-świerkowych wschodniej i środkowej Europy może być jeszcze większa i dochodzić do 500-1000 $\mathrm{m}^{3} / \mathrm{ha}$ (GUTOwSKI i in. 2004), a nawet do $1267 \mathrm{~m}^{3} / \mathrm{ha}$ w pierwotnych lasach borealnych północnej Rosji (SHorohova \& KAPITSA 2015). W lasach gospodarczych Europy jest ona zdecydowanie niższa i w większości przypadków nie przekracza $25 \mathrm{~m}^{3} / \mathrm{ha}$ (SEIDLING i in. 2014). Zdaniem NiLSSONA i in. (2002), zasobność lasów europejskich w martwe drzewa przed rozpoczęciem ich eksploatacji wynosiła $130-150 \mathrm{~m}^{3} / \mathrm{ha}$.

Zasoby drzew martwych na badanej powierzchni nie były swobodnie kształtowane w wyniku działania naturalnych procesów ekologicznych, takich jak śmiertelność czy konkurencja międzyosobnicza i międzygatunkowa. Do 1993 r. obserwowano tu prowadzenie czynności gospodarczo-leśnych, zapisanych w planach urządzania lasu Nadleśnictwa Katowice, co było zgodne ze statusem rezerwatu częściowego. Wpływ na śmiertelność drzew miał również w 2001 r. huraganowy wiatr, który przyczynił się do powstania licznych wiatrołomów, zwłaszcza wśród olch czarnych. Zapewne oddziaływanie tych czynników osłabiło zależność między powierzchnią przekroju poprzecznego drzew żywych a objętością martwych drzew, która została wykazana przez NiLssona i in. (2002), na co zwrócili uwagę NORDÉN i in. (2004). Zależność ta dla olszy czarnej i wiązów górskich oraz dębów i wszystkich drzew na powierzchni badawczej była słaba, o czym świadczą wyliczone współczynniki determinacji $\left(\mathrm{R}^{2}\right)$, wynoszące odpowiednio: $0,21,0,36$ i 0,37 . Jeszcze słabszą zależność obliczono dla objętości drzew martwych i żywych $\left(\mathrm{R}^{2}<0,3\right)$.

Mimo iż rezerwat przyrody „Ochojec” jest częściowym rezerwatem florystycznym, to jednak zasoby drzew martwych powinny w nim podlegać ochronie. Od tych zasobów zależne jest funkcjonowanie ekosystemów leśnych, a także różnorodność biologiczna rezerwatu, w szczególności zaś bogactwo fauny bezkręgowców oraz grzybów i śluzowców związanych z martwymi drzewami. Drzewa te są istotnym siedliskiem dla reliktowych i puszczańskich gatunków chrząszczy saproksylicznych (SzOŁTYs 2009) i grzybów większych (KARASIŃSKI 2009), których występowanie stwierdzono dotychczas w rezerwacie.

Gospodarowanie zasobami drzew martwych w rezerwacie przyrody „Ochojec” nie jest łatwym zadaniem. Biorąc pod uwagę lokalizację oraz obserwowany poziom antropopresji, rozmieszczenie przestrzenne i objętość drzew martwych muszą podlegać kontroli, która uwzględni także kwestie bezpieczeństwa przeciwpożarowego oraz zdrowia mieszkańców i zwiedzających. Powiększające się z roku na rok zasoby martwych drzew mogą być cennym obiektem dydaktycznym w rezerwacie.

Podziękowania. Autor składa podziękowania dwóm anonimowym recenzentom za uwagi, dzięki którym jego praca stała się lepsza. Dziękuje także studentom Uniwersytetu Śląskiego w Katowicach za pomoc w pracach pomiarowych w 2004 r. Badania sfinansowane z budżetu Centrum Dziedzictwa Przyrody Górnego Śląska w Katowicach. 


\section{LITERATURA}

BehnKe-Borowczyk J., Kwaśna H., Kokot K., Hąuszczak M., Kartawik N. \& Łakomy P. 2018. Żywe-martwe drewno. - W: D. ToMASZEWSKI \& A. M. JAGODZIŃSKI (red.), Biologia i ekologia roślin drzewiastych. Konferencja naukowa połączona z obchodami Jubileuszu 85-lecia Instytutu Dendrologii PAN w Kórniku, Kórnik - Poznań, 11-15 czerwca 2018. Materiały konferencyjne, s. 194-196. Bogucki Wydawnictwo Naukowe, Poznań.

BŁońsKa E., LASOTA J. \& PiAsZCZYK W. 2019. Zapas i struktura martwego drewna oraz jego znaczenie w akumulacji węgla na siedliskach lasu wilgotnego oraz olsu jesionowego. - Sylwan 163(2): 141-149.

BRUChwald A. 1986. Dendrometria. s. 279. Wydawnictwo SGGW-AR, Warszawa.

Bujoczer L., SzewczyK J. \& Bujoczek M. 2018. Deadwood volume in strictly protected, natural, and primeval forests in Poland. - European Journal of Forest Research 137: 401-418.

Chmura D., SzPYRKa S. \& BeczaŁa T. 2017. Ocena stanu zachowania drzewostanu w rezerwacie przyrody „Skarpa Wiślicka” na Pogórzu Śląskim. - Inżynieria Ekologiczna 18(2): 1-8.

Christensen M., Hahn K., Mountford E. P., Ódor P., Standovár T., Rozenbergar D., Diaci J., WiJDEVEn S., MeYer P., Winter S. \& VRSKA T. 2005. Dead wood in European beech (Fagus sylvatica) forest reserves. - Forest Ecology and Management 210: 267-282.

CofaŁa J. P. 2009. Znaczenie posuszu dla różnorodności biologicznej w rezerwacie „Ochojec”. s. 125. Mskr. pracy magisterskiej, Katedra Geobotaniki i Ochrony Przyrody, Wydział Biologii i Ochrony Środowiska, Uniwersytet Śląski, Katowice.

CZEREPKo J. (red.). 2008. Stan różnorodności biologicznej lasów w Polsce na podstawie powierzchni obserwacyjnych monitoringu. Synteza wyników uzyskanych w ramach realizacji projektu BioSoil Forest Biodiversity. s. 135. Instytut Badawczy Leśnictwa, Sękocin Stary.

CZEREPKo J., HilszCZAŃski J. \& JABŁoŃSKi M. 2014. Martwe drewno - żywy problem. - Studia i Materiały Centrum Edukacji Przyrodniczo-Leśnej w Rogowie 41(4): 36-45.

Czuraj M. 1990. Tablice zasobności i przyrostu drzewostanów. s. 167. Państwowe Wydawnictwo Rolnicze i Leśne, Warszawa.

CZuraj M., Radwański B. \& Strzemski S. 1966. Tablice miąższości drzew stojących. s. 192. Państwowe Wydawnictwo Rolnicze i Leśne, Warszawa.

Dittrich S., Jacob M., Bade C., Leuschner Ch. \& Hauck M. 2014. The significance of deadwood for total bryophyte, lichen, and vascular plant diversity in an old-growth spruce forest. - Plant Ecology 215: $1123-1137$.

DUDZIŃSKA M. \& BRUCHWALD A. 2003. Wzory empiryczne i tablice miąższości grubizny drzewa dla olszy czarnej (Alnus glutinosa (L.) Gaertn.). - Sylwan 147(6): 69-78.

European Environmental Agency. 2015. Forest: deadwood. Indicator Specification, Indicator codes: SEBI 018. European Environment Agency, Copenhagen, Denmark. https://www.eea.europa.eu/dataand-maps/indicators/forest-deadwood-1 (dostęp: 15.01.2020).

Forest STEWARDShIP COUNCIL. Międzynarodowy standard FSC. Zasady i kryteria FSC w zakresie gospodarki leśnej. FSC-STD-01-001 V5-2. s. 31. Zatwierdzony 22 lipca 2015 r. FSC International Center, Bonn, Niemcy.

Gao T., Nielsen A. B. \& Hedblom M. 2015. Reviewing the strength of evidence of biodiversity indicators for forest ecosystems in Europe. - Ecological Indicators 57: 420-434.

GóRAK A. 2010. Miąższość martwego drewna w rezerwacie „Ochojec” w Katowicach. s. 120. Mskr. pracy magisterskiej, Katedra Geobotaniki i Ochrony Przyrody, Wydział Biologii i Ochrony Środowiska, Uniwersytet Śląski, Katowice. 
Gutowski J. M. (red.), Bobiec A., Pawlaczyk P. \& Zub K. 2004. Drugie życie drzew. s. 245. WWF Polska, Warszawa - Hajnówka.

HAhn K. \& Christensen M. 2004. Dead wood in European forest reserves - a reference for forest management. - W: M. MARCHETTI (red.), Monitoring and indicators of forest biodiversity in Europe. EFI Proceedings No 51: 49-77.

Harmon M. E., Franklin J. F., Swanson F. J., Sollins P., Gregory S. V., Lattin J. D., Anderson N. H., Cline S. P., Aumen N. G., Sedell J. R., Lienkaemper G. W., Cromack Jr K. \& Cummins K. W. 1986. Ecology of coarse woody debris in temperate ecosystems. - Advances in Ecological Research 15: $133-302$.

HoleKsA J., ŻywIEC M. \& KUREK P. 2014. Ilość obumarłych drzew w lasach gospodarczych w związku z wymaganiami ochrony przyrody na obszarach Natura 2000 - od statycznego do dynamicznego podejścia. - Studia i Materiały Centrum Edukacji Przyrodniczo-Leśnej w Rogowie 41(4): 15-29.

JAWORSKI A. \& PACH M. 2014. Stan wielogatunkowego lasu naturalnego (Abies, Fagus, Picea) regla dolnego w rezerwacie Oszast na tle stanu monokultur świerkowych w Beskidzie Żywieckim i Beskidzie Śląskim. - Leśne Prace Badawcze 75(1): 13-23.

JAworski A., KoŁodZiEj Z. \& PACH M. 2001a. Skład gatunkowy, budowa i struktura drzewostanów w rezerwacie „Śrubita”. - Sylwan 155(6): 21--47.

JAwOrSKi A., Kołodziej Z. \& StrZĄSKa T. 2001b. Skład gatunkowy, budowa i struktura drzewostanów w rezerwacie Oszast. - Sylwan 145(4): 5-32.

KARASIŃSKI D. 2009. Grzyby większe rezerwatu przyrody „Ochojec”. - W: J. B. PARUSEL (red.), Rezerwat przyrody Ochojec w Katowicach (Górny Śląsk). Monografia naukowo-dydaktyczna. s. 86-103, 470. Centrum Dziedzictwa Przyrody Górnego Śląska, Katowice.

KARCZMARSKI J. \& BĄK M. 2010. Skład gatunkowy, budowa i struktura oraz kierunki przemian drzewostanu z udziałem świerka w przygrzbietowej części rezerwatu Madohora w Beskidzie Małym. - Leśne Prace Badawcze 71(4): 369-380.

KARCZMARSKi J. \& KowALCZUK P. 2007. Budowa, struktura i dynamika górnoreglowego boru świerkowego o charakterze pierwotnym w rezerwacie Romanka w Beskidzie Żywieckim (w okresie kontrolnym 1993-2004). - Acta Agraria et Silvestria, Series Silvestris 45: 39-71.

KARPIŃSKi L. M. 2017. Porównanie zgrupowań kózkowatych (Coleoptera: Cerambycidae) wybranych rezerwatów przyrody i obszarów niechronionych województwa śląskiego. s. $189+14$ tab. Mskr. pracy doktorskiej, Katedra Zoologii, Uniwersytet Śląski, Katowice.

Kraus D. \& KRUMm F. (red.). 2013. Integrative approaches as an opportunity for the conservation of forest biodiversity. s. 284. European Forest Institute, Freiburg.

Kunttu P., JunNinen K. \& Kouki J. 2015. Dead wood as an indicator of forest naturalness: A comparison of methods. - Forest Ecology and Management 353: 30-40.

Linder P., ElfVing B. \& Zackrisson O. 1997. Stand structure and successional trends in virgin boreal forest reserves in Sweden. - Forest Ecology and Management 98: 17-33.

Maser Ch. \& Trappe J. M. (red.). 1984. The seen and unseen world of the fallen tree. s. 56. Pacific Northwest Forest and Range Experiment Station USDA Forest Service, General Technical Report PNW-164.

MAŚLAK M. \& ORCZEWSKA A. 2010. Zasoby martwego drewna w zbiorowiskach kwaśnej buczyny niżowej leśnych obszarów chronionych Górnego Śląska. - Studia i Materiały Centrum Edukacji Przyrodniczo-Leśnej w Rogowie 25(2): 369-376.

Merganičová K., Merganič J., Svoboda M., BaČe R. \& Šebeň V. 2012. Deadwood in forest ecosystems. - W: J. A. BlAnco \& Y-H. Lo (red.), Forest ecosystems - more than just trees, s. 81-108. InTech, Rijeka, Croatia. 
MÜLLER J. \& BÜTLER R. 2010. A review of habitat thresholds for dead wood: a baseline for management recommendations in European forests. - European Journal of Forest Research 129: 981-992.

Nilsson S. G., Niklasson M., Hedin J., Aronsson G., Gutowski J. M., Linder P., Ljungberg H., Mikusinski G. \& Ranius T. 2002. Densities of large living and dead trees in old-growth temperate and boreal forests. - Forest Ecology and Management 161: 189-204.

Nordén B., Götmark F., TÖnnberg M. \& RYberg M. 2004. Dead wood in semi-natural temperate broadleaved woodland: contribution of coarse and fine dead wood, attached dead wood and stumps. - Forest Ecology and Management 194: 235-248.

PARUSEL J. B. 1989. Dewastacja przyrody rezerwatu florystycznego Ochojec w granicach miasta Katowice. - Chrońmy Przyrodę Ojczystą 45(1): 45-48.

Parusel J. B. 2003. Populacja liczydła górskiego Streptopus amplexifolius (L.) DC. w Katowicach (1973-2003). - Acta Facultatis Rerum Naturalium Universitatis Ostraviensis 211, Biologia - Ekologia 10: $18-23$.

Parusel J. B. 2009a. Roślinność rezerwatu przyrody „Ochojec”. - W: J. B. Parusel (red.), Rezerwat przyrody Ochojec w Katowicach (Górny Śląsk). Monografia naukowo-dydaktyczna, s. 212-235, 475, 511-546. Centrum Dziedzictwa Przyrody Górnego Śląska, Katowice.

Parusel J. B. 2009b. Struktura i dynamika drzewostanu łęgu jesionowo-olchowego w rezerwacie przyrody „Ochojec”. - W: J. B. PARUSEL (red.), Rezerwat przyrody Ochojec w Katowicach (Górny Śląsk). Monografia naukowo-dydaktyczna, s. 236-243, 475-476. Centrum Dziedzictwa Przyrody Górnego Śląska, Katowice.

PARUSel J. B. \& Bula R. 2009. Mapa roślinności rzeczywistej rezerwatu przyrody „Ochojec” w Katowicach. - W: J. B. PARUSEL (red.), Rezerwat przyrody Ochojec w Katowicach (Górny Śląsk). Monografia naukowo-dydaktyczna, s. 592. Centrum Dziedzictwa Przyrody Górnego Śląska, Katowice.

Pasierbek T., Holeksa J., Wilczek Z. \& Żywiec M. 2007. Why the amount of dead wood in Polish forest reserves is so small? - Nature Conservation 64: 65-71.

Pawicka K. \& Woziwoda B. 2011. Bilans martwego drewna w rezerwacie „Polesie Konstantynowskie”. - Sylwan 155(12): 851-858.

PAWLACZYK P. 2010. 91E0* Łęgi wierzbowe, topolowe, olszowe i jesionowe Salicetum albae, Populetum albae, Alnenion glutinoso-incanae, olsy źródliskowe. s. 236-254. - W: W. Mróz (red.), Monitoring siedlisk przyrodniczych. Przewodnik metodyczny. Cz. I. Biblioteka Monitoringu Środowiska, GIOŚ, Warszawa. Modyfikacja metodyki monitoringu opublikowanej w W. Mróz (red.). 2010. Daty wprowadzenia modyfikacji do prac monitoringowych: 2012-07-31, 2015-07-17.

PAWLACZYK P. 2016. Martwe drzewa w ochronie żywej przyrody. - W: A. WikŁo (red.), Stan ekosystemów leśnych Puszczy Białowieskiej. Ogólnopolska Konferencja Naukowa Ministerstwa Środowiska i Generalnej Dyrekcji Lasów Państwowych 28.10.2015, Warszawa, s. 59-86. Centrum Informacyjne Lasów Państwowych, Warszawa.

Plan UrząZEnia Gospodarstwa Leśnego Nadleśnictwa państwowego Katowice obręb Murcki na okres gospodarczy od 1.X.1976 do 30.IX.1981. Cz. II. Opis taksacyjny lasów wg stanu na 1.X.1976.

PlAn URZĄDZENIA Lasu dla Nadleśnictwa Katowice na okres gospodarczy od 1 stycznia 2010 r. do 31 grudnia 2019 r. Ogólny opis lasów Nadleśnictwa. Biuro Urządzania Lasu i Geodezji Leśnej Oddział w Krakowie. Regionalna Dyrekcja Lasów Państwowych w Katowicach.

ProJeKT planu Urządzenia lasu dla Nadleśnictwa Katowice na okres gospodarczy od 1 stycznia 2020 r. do 31 grudnia 2029 r. Nadleśnictwo Katowice, Katowice.

Referowska-ChODAK E. 2014. Problematyka martwego drewna i drzew dziuplastych w systemach certyfikacji FSC i PEFC. - Studia i Materiały Centrum Edukacji Przyrodniczo-Leśnej w Rogowie 41(4): 98-115. 
Schuck A., Meyer P., Menke N., Lier M. \& Lindner M. 2004. Forest biodiversity indicator: dead wood - a proposed approach towards operationalising the MCPFE. - W: M. MARCHETTI (red.), Monitoring and indicators of forest biodiversity in Europe. EFI Proceedings No 51: 49-77.

Seidling W., Travaglini D., Meyer P., Waldner P., Fischer R., Granke O., Chirici G. \& Corona P. 2014. Dead wood and stand structure - relationships for forest plots across Europe. - iForest 7: 269-281.

Shorohova E. \& Kapitsa E. 2015. Stand and landscape scale variability in the amount and diversity of coarse woody debris in primeval European boreal forests. - Forest Ecology and Management 356: 273-284.

SOLON J. 2002. Ekologiczna rola martwego drewna w ekosystemach leśnych - dyskusja wybranych zagadnień w świetle literatury. - W: A. BreyMeyer, M. Degórski, E. Roo-ZielińsKa, J. SOlon \& J. Wolski, Podstawy trwałego i zrównoważonego zagospodarowania lasów w Leśnych Kompleksach Promocyjnych. Martwe drewno i jego funkcje ekologiczne w lasach zagospodarowanych i rezerwatach wybranych LKP. Sprawozdanie z III etapu, s. 15. Instytut Badawczy Leśnictwa, Sękocin Las.

Stokland J. N., Sirtonen J. \& Jonsson B. G. 2012. Biodiversity in dead wood. s. 524. Cambridge University Press, Cambridge, UK.

SzOŁTYs H. 2009. Saproksyliczne chrząszcze (Coleoptera) rezerwatu przyrody „Ochojec”. - W: J. B. PARuSEl (red.), Rezerwat przyrody Ochojec w Katowicach (Górny Śląsk). Monografia naukowo-dydaktyczna, s. 168-170, 472, 508-509. Centrum Dziedzictwa Przyrody Górnego Śląska, Katowice.

TABOR J. 2014. Kryteria oceny zasobów martwego drewna w Polsce i Europie. - Studia i Materiały Centrum Edukacji Przyrodniczo-Leśnej w Rogowie 41(4): 46-60.

VítKová L., BaČE R., KuUČUkov P. \& Svoboda M. 2018. Deadwood management in Central European forests: key considerations for practical implementation. - Forest Ecology and Management 429: 394-405.

WielkoobsZarowa inwentaryzacja stanu lasów w Polsce. 2019. Wyniki za okres 2014-2018. Etap 2.5.1.b. s. 95 + ryciny i tabele. Biuro Urządzania Lasu i Geodezji Leśnej, Sękocin Stary.

Zielonka T., Izworska K., Kapusta P., Kurek P., Piechnik Ł., Szarek-ŁukaszewsKa G., Żywiec M. \& Holeksa J. 2018. Martwe drzewa w lesie gospodarczym - ilość, jakość, rozmieszczenie. - W: D. TOMASZEWSKi \& A. M. JAGODZIŃSKI (red.), Biologia i ekologia roślin drzewiastych. Konferencja naukowa połączona z obchodami Jubileuszu 85-lecia Instytutu Dendrologii PAN w Kórniku, Kórnik - Poznań, 11-15 czerwca 2018. Materiały konferencyjne, s. 185-186. Bogucki Wydawnictwo Naukowe, Poznań.

\section{SUMMARY}

The paper presents the results of the author's long-term research on the structure and dynamics of dead trees in Fraxino-Alnetum ash-alder forest in the Ochojec Nature Reserve. The results are compared with data collected for living trees.

Tree measurements were made in 1979, 1987, 2004 and 2019 in a 0.57 ha permanent research plot established in a Fraxino-Alnetum forest stand on the right slope of the Ślepiotka river valley in 1979. The measurements included diameter at breast height, height, and crown base height of all living trees and standing dead trees. The number of lying dead trees was estimated on the basis of the decrease in the number of standing trees measured in 1987, 2004 and 2019. The volume and basal area information for whole trees were obtained from volume tables for standing trees, while for lying dead trees it was calculated using Huber's formula.

During the research period (1979-2019), 17 species of living trees and shrubs were found on the plot. They varied in density from 639 to $432 \mathrm{pcs} / \mathrm{ha}$ (Tab. 1). The dbh distribution was left-skewed (Fig. 2). Their basal area increased from 27.05 to $43.50 \mathrm{~m}^{2} / \mathrm{ha}$, as did the volume of timber (from 247.99 to $527.36 \mathrm{~m}^{3} / \mathrm{ha}$ ) 
(Tab. 1). The dominant species in the stand is black alder. The undergrowth consists mostly of pedunculate oak and rowan.

The share of standing dead trees in the stand was small: five trees were found $1987(0.9 \% \mathrm{~N} / \mathrm{ha}$ and $0.02 \% \mathrm{~V} / \mathrm{ha}$ of living trees), 55 trees in 2004 (10.2\% and 1.8\%) and 51 trees in $2019(11.8 \%$ and $0.8 \%)$ (Tab. 2). The dbh distribution was left-skewed (Fig. 3). Oak and rowan dominated in numbers, and black alder in volume. The volume of standing dead trees decreased from $7.28 \mathrm{~m}^{3} / \mathrm{ha}$ in 2004 to $4.42 \mathrm{~m}^{3} / \mathrm{ha}$ in 2019 (Tab. 2).

Lying dead trees form the coarse woody debris. In 2004, 147 trees (which were measured as standing in 1987) with total volume of $15.86 \mathrm{~m}^{3} /$ ha were lying on the plot's floor. In 2019, another 174 trees (measured as standing in 2004) with total volume of $24.82 \mathrm{~m}^{3} /$ ha were on the plot's floor. Oak and rowan dominated in number, and black alder in volume (Tab. 2). The dbh distribution was left-skewed (Fig. 4).

Currently, dead trees do not play a major role in the structure of the Fraxino-Alnetum ash-alder forest stand. The total number of dead standing trees was $0.8 \%$ of the number of living trees in $1987,10.2 \%$ in 2004 , and $11.8 \%$ in 2019 (Tabs 1, 2). The total volume of dead standing trees was $0.02 \%$ of the total volume of living trees in 1987, 2.0\% in 2004, and $0.6 \%$ in 2019.

The volume of standing dead trees in the studied area is currently greater than the volume of standing dead trees in commercial forest stands administered by the Regional Directorate of State Forests (RDLP) in Katowice (gross merchantable timber: $3.8 \mathrm{~m}^{3} / \mathrm{ha}$ ), and the volume reported in stands administered by the State Forests (gross merchantable timber: $3.7 \mathrm{~m}^{3} / \mathrm{ha}$ ). The volume of standing dead trees in the Ochojec Nature Reserve is also greater than the volume of standing and lying dead trees reported in 2019 in the alder stand administered by the Katowice Forest Inspectorate $\left(2.98 \mathrm{~m}^{3} / \mathrm{ha}\right.$ on the alder site) and lower than the volume of standing and lying dead trees found on the ash-alder site $\left(8.28 \mathrm{~m}^{3} / \mathrm{ha}\right)$.

In the ash-alder swamp forest ecosystem, on the other hand, the share of lying dead trees is considerable (Tab. 2). The total number of lying dead trees in 2004 constituted $26.9 \%$ of the number of living trees, and in 2019 it accounted for as much as $40.3 \%$ (Tabs 1,2). The total volume of lying dead trees constituted $3.9 \%$ of the total volume of living trees in 2004 , and $4.7 \%$ in 2019 . The combined volume of the trees downed in 1987-2004 and 2004-2019 amounts to $40.68 \mathrm{~m}^{3} / \mathrm{ha}$, significantly more than the current volume of lying dead trees in the commercial forest stands administered by the Regional Directorate of State Forests (RDLP) in Katowice (gross merchantable timber: $3.7 \mathrm{~m}^{3} / \mathrm{ha}$ ) and the volume reported in stands administered by the State Forests (gross merchantable timber: $3.8 \mathrm{~m}^{3} / \mathrm{ha}$ ). It is also greater than the volume of lying trees and fragments of dead trees reported in 2019 in the alder stand administered by the Katowice Forest Inspectorate (gross merchantable timber: $5.34 \mathrm{~m}^{3} / \mathrm{ha}$ in the alder site) and in the ash-alder swamp forest $\left(2.54 \mathrm{~m}^{3} / \mathrm{ha}\right)$.

As compared to the volume reported in other reserves of Silesia Province, the volume of dead trees in the Ochojec Nature Reserve in Katowice is not high. The average volume calculated for 15 reserves is $136 \mathrm{~m}^{3} / \mathrm{ha}$, including $66 \mathrm{~m}^{3} / \mathrm{ha}$ for standing dead trees and $70 \mathrm{~m}^{3} / \mathrm{ha}$ for lying dead trees. A comparison of the volume of dead trees in the Ochojec Nature Reserve with reserves protecting the same or similar habitats shows that it corresponds to the volume reported for the Babczyna Dolina Nature Reserve $\left(26.25 \mathrm{~m}^{3} / \mathrm{ha}\right.$, only lying dead trees) and is significantly lower than the volume documented in the Polesie Konstantynowskie Nature Reserve $\left(38.91 \mathrm{~m}^{3} / \mathrm{ha}\right.$ of dead trees, including $24.90 \mathrm{~m}^{3} / \mathrm{ha}$ of lying trees and $13.62 \mathrm{~m}^{3} / \mathrm{ha}$ of standing trees) and in the Czarna Rózga Nature Reserve (standing trees: $11.78 \mathrm{~m}^{3} / \mathrm{ha}$ of whole trees and $3.35 \mathrm{~m}^{3} / \mathrm{ha}$ of stumps; lying trees: $35.45 \mathrm{~m}^{3} / \mathrm{ha}$ of whole trees and $1.47 \mathrm{~m}^{3} / \mathrm{ha}$ of stumps).

The volume of dead trees on the studied plot was not shaped freely by natural ecological processes such as mortality or inter-individual and interspecific competition, because, until 1993, forestry activities were conducted there as part of forest management plans of the Katowice Forest Inspectorate, with Ochojec being only under partial protection. A severe windstorm in 2001 also had an impact on tree mortality and caused numerous windthrows, especially among black alders.

Wptynęto: 31.01 .2020 r.; przyjęto do druku: 18.05.2020 r. 